Giovanna Calasso

\title{
Constructing the Boundary between Mashriq and Maghrib in Medieval Muslim Sources
}

\section{Categorizing the world}

The classification of the world's many facets - its territories, populations, languages and history - is one of the fields where the differences between cultures become most evident. Likewise, within a single cultural milieu, such classifications reveal the changes that occur over time in the way of conceiving oneself and others. It is also a field where the need to separate, to establish differences, and thus identities, is continuously held in check by networks of relationships that prove divides wrong, contradicting labels and classifications.

The second volume of the New Cambridge History of Islam, entitled The Western Islamic World: Eleventh to Eighteenth Centuries, is a case in point. At first glance, it follows a rather unusual geopolitical structure, including, apart from the predictable first section on "Al-Andalus and North and West Africa (Eleventh to Fifteenth Centuries)", a second one on Egypt and Syria (11th c. until the Ottoman conquest), as well as a third one on Muslim Anatolia and the Ottoman Empire. It then returns to "North and West Africa (Sixteenth to Eighteenth Centuries)", and concludes with a chapter dedicated to the "Ottoman Maghreb". Thus, the label "Western Islamic World", considered over a period spanning from the 11th century to the 18th century, applies here to a much wider geographical domain than one might expect. However, as can be inferred from Maribel Fierro's introduction to the volume, the Mediterranean orientation of the political powers and commercial trends, as well as the encounter/clash with Christian Europe, are the main elements binding together geographical areas that are not always strictly “western". Meanwhile, the regions viewed as the Islamic East - including Iran and Central Asia - were much more profoundly influenced by the encounter/clash with Indian and Chinese civilizations. ${ }^{1}$ Yet, as observed by the editors of the volume dedicated to The Eastern Islamic World, "crudely severing the lands

1 Fierro 2010, 1-2.

Note: English revision by Nicholas Callaway.

2 Open Access. ( 2021 Giovanna Calasso, published by De Gruyter. (cc) )BY-NC-ND This work is licensed under the Creative Commons Attribution-NonCommercial-NoDerivatives 4.0 International License. https://doi.org/10.1515/9783110713305-002 
of Islam into two halves can easily generate the impression of a much greater divergence than was the case in reality", ${ }^{2}$ while at the same time the features that identify each of the two halves do not necessarily constitute a unitary reality. As Elton Daniel points out, if "Iran and the Islamic east can be understood as referring to those parts of the Islamic oecumene that had formerly been part of the Sasanian empire and where Islam came to be the dominant religion, but where Arabic did not establish itself as the vernacular language of the majority of the population", ${ }^{3}$ in fact "the Islamic east was not 'a region' so much as a group of regions [...] with great variations in terms of relations both with each other and with the greater commonwealth of the caliphate". ${ }^{4}$

But how was the Islamic world seen from within, particularly by its own historians and geographers, as the actual or alleged unity of the great Caliphate stretching from Iberia to India progressively crumbled and new political powers came to the fore, while conflicts as well as diplomatic and commercial contacts with Europe - or, conversely, with India and China - shaped culturally diversified areas?

The aim of this chapter, then, is to explore when and how a boundary between Mashriq and Maghrib was conceived in medieval Muslim sources, and which elements can be identified as being at the basis of this dichotomy, as explicitly or implicitly found in geographical and historical works by Eastern and Western Muslim authors from the 3rd-4th/9th-10th century to the 6th-7th/12th13th century, as well as in travel literature. The relationship between mapping the world in terms of dār al-islām and dār al-ḥarb - "the abode of Islam" and "the abode of war" ${ }^{5}$ - and mapping the world of Islam itself in terms of East and West - mashriq and maghrib - will also be the object of some comparative remarks. Indeed, this study revolves around words which outline boundaries and convey different categorizations of the world and its inhabitants - us/them or inside/outside dichotomies - describing divisions even within the Islamic world. Such categorizations and dichotomies reflect, with varying degrees of clarity, different historical moments marked by major changes inside and outside the world under Muslim rule.

The binary dār al-islām/dār al-ḥarb was conceived by jurists of the entourage of the 'Abbāsid caliphs in Baghdad following the stabilization of the vast ArabMuslim territorial expansion, which had reached its peak under the Umayyads.

2 Morgan/Reid 2010, 2.

3 Daniel 2010, 448.

4 Daniel 2010, 449.

5 On this topic, see Calasso/Lancioni 2017. 
Devised by jurists as a necessary analytical instrument to deal mainly with the laws of warfare, it would also become the framework in which rules were established to manage a reality made up of movements, exchanges and relationships between individuals residing both inside and outside the domains of Islam. ${ }^{6}$ More importantly, apart from their technical meaning in legal texts, dār al-islām and dār al-harb are two terms which have to do with the crucial issue of how to conceive of oneself and others, and how to translate this conception into words. In fact, these words were at first a terminological array that at a certain point crystallized into two conventional formulas, ${ }^{7}$ constituting an oppositional pair, which would persist up to modern and contemporary times.

Unlike the dār dichotomy, the pair maghrib/mashriq, which has also persisted up to the present, arose in the 4th/10th century in Eastern geographical texts describing the lands of Islam. In the following pages it will be shown that also this binary - as used by Muslim geographers and travellers between the 4th/10th century and the 7th/13th century - reveals a complexity which goes far beyond descriptive geography, insofar as it introduces a dichotomy within "the realm of Islam". As Ralph Brauer has demonstrated in his thorough analysis of 3rd-6th/9th-12th-century Muslim geographical sources, "apart from sea frontiers, sharply defined boundary lines within the Islamic empire were either nonexistent or of little practical importance". ${ }^{8}$ This is true even after the breakup of the empire and the formation of numerous dynastic domains. Yet, does this neglect of inland boundaries between different (Muslim) political entities - as can be found in cartography, in geographical and historical writings, as well as in travelogues - "reflect certain fundamental traits of the intellectual or religious culture of the Islamic empire"? In other words, should this neglect be considered a consequence of "embedded attitudes" of Muslim culture?" If we consider Muslim geographers and travellers' mental maps of their own world, we will find that internal boundaries clearly did exist, albeit between broader regions including the domains of multiple dynasties. However, to understand exactly what kinds of boundaries are at play here, it is crucial to highlight the historical framework in which they developed.

\footnotetext{
6 Calasso 2010, 281-286; Calasso 2017, 25, 29-31.

7 See Lancioni 2017, 415-425.

8 Brauer 1995, 36.

9 Brauer 1995, 40-44.
} 


\section{Dār al-islām/dār al-ḥarb, bilād al-islām/bilād al-rūm, the Rūm and the Ifranj}

Since the Persian Empire was removed from the political scene of the Near East in the mid-7th century CE, the territorial and political reality of dār al-harb largely overlapped with the Byzantine Empire, mostly referred to by Muslim geographers and historians as bilād al-Rūm. Even in the works of 4th/10th-century geographers, who deliberately focused on describing Islamic lands, almost completely neglecting the "outside world", ${ }^{10}$ the expression dār al-islām rarely occurs - further proof of its being an abstract legal category. However, geographers did make use of other general and equally all-embracing expressions, such as bilād alislām or mamlakat al-islām, as well as the word islām itself used in a spatial sense. Thus, on the whole, their perception of the existence of two distinct realms, one of which was identified by the reference to Islam, was similar to the binary emerging from legal texts.

As for Muslim historians, they do not usually employ the two oppositional terms coined by jurists either, and, even when describing the wars of conquest, simply name enemy territories after their inhabitants, i.e. bilād al-Rūm. For these territories, in particular for the Byzantine-Anatolian borders, which, still at the time of Hārūn al-Rashīd (r. 170-193 H/786-809 CE), the Muslims' jihād campaigns continued to target primarily, geographers and historians even created a specific frontier terminology, thughūr and 'awāșim. ${ }^{11}$ This is also the period in which jurists such as Abū Yūsuf (d. 182 H/798 CE) and al-Shaybānī (d. 189 H/805 CE) - both disciples of Abū Hanīfa (d. 150 H/767 CE) - started to use systematically the notions of dār al-islām and dār al-harb in their works. Even so, the boundary between the two dārs is not mentioned in their writings, although it implicitly represents the raison d'être of this binary. Rather, they constantly evoke it through verbs of movement, mainly dakhala fi / kharaja min (to enter/to exit), since it is crossing this unspoken frontier which will have legal consequences.

Starting from the end of the 5th/11th century, a major historical change occurred, whereby the dār al-harb par excellence became the Christian Europe or

10 Zayde Antrim, however, suggests that Ibn Hawqal's text is actually much more engaged with lands outside "the realm of Islam" than his regional divisions might suggest. See Antrim 2012, 119. See also Martinez-Gros 1998, 326-327.

11 See Bonner 1994, who outlines the long process that resulted in the 'awāṣim and thughūr system, even though most sources agree in attributing it to the reign of Hārūn al-Rashīd. 
Latin Christendom of the Ifranj, while much of Anatolia by now included territories subject to Muslim authority. But the words - at least certain words - persist over time. Muslim jurists' categories and terms - dār al-islām/dār al-ḥarbwould continue to be used up to modern times, with shifting meanings and boundaries, ${ }^{12}$ as did the words Rūm and rūmi until the late Middle Ages, becoming less precise and more all-embracing in their use. ${ }^{13}$ Although al-Ifranj was the name Eastern Muslim historians used for crusaders and, more generally, Latin Christians, in contrast to Rūm/rūmi - Byzantine Christians - in many cases the latter designation would eventually be used interchangeably for both. Out of many possible examples, it would be enough to quote a passage from Ibn Jubayr's Rihla (late 6th/12th century) in which the traveller, when mentioning the great defensive works Șalāh al-Dīn (Saladin) was building in Cairo, such as the citadel and the city walls, writes: "The forced labourers on this construction (...) were the foreign Rumi prisoners whose numbers were beyond computation". ${ }^{14}$ In this context, the "Rumi prisoners" can only be Latin Christians who were captured during the constant military expeditions taking place between Muslims and crusaders.

The looseness of the terms Rūm/rūmì has received the most attention in studies of medieval texts concerning commercial relations. For instance, Jessica Goldberg, who has recently carried out a thorough critical analysis of the Cairo Geniza materials and their interpretation, observes:

The eleventh-century Geniza does not record a single profitable trading venture to the north, within the frontiers of the large area known undifferentiatedly as balad al-Rūm -that is, the land of the Romans. To the Geniza merchants the people of these regions were Rūm, Romans - regardless of whether they were from the Northern Italian maritime republics, Byzantine Italy, Greece, or Asia Minor. ${ }^{15}$

Thus, Jews living in Muslim lands used the same basic terminology for the Christian world as those used by Muslims. ${ }^{16}$ The Geniza commercial documents reveal

12 Besides the different theoretical orientations of Muslim jurists, the changes in historical circumstances inevitably gave rise to different ways of understanding the two terms through time. Over the centuries, Muslims constituted by turns a minority ruling over a majority made up of members of other religious communities, a ruling majority, a religious majority under non-Muslim political rule, and, in different contexts in early modern and modern times, a minority residing in "non-Muslim" countries (see Calasso 2017, 39). On this last issue see Abou El Fadl 1994.

13 Examples of the persisting undifferentiated usage of the term Rūm for Byzantium/Byzantines and for Europeans as well, can be found in Lev 2017, 63-73.

14 See Ibn Jubayr, Travels (1952), 43; Rị̣la (1907), 51 (al-asārā min al-rūm).

15 Goldberg 2012, 306-307.

16 See Lev 2017, 72. 
a similar lack of precision regarding the area called the Maghrib and its people, the Maghäriba. Shelomo Dov Goitein was the first to call attention to the broad geographical meaning of terms such as Maghrib, comprising the entire Muslim Mediterranean world west of Egypt (North Africa, al-Andalus and Sicily) and $R \bar{u} m$, in the Geniza commercial documents designating both Byzantium and Christian Europe in general. According to Goitein,

The terminology [in the Geniza documents] betrays the existence of a deep barrier between the Muslim East and the Muslim West and between both and Europe (including Byzantine Asia Minor). When a person describes another as a Rūmī or a Maghribī, without specifying his city or country, he shows lack of familiarity with, or interest in, the latter's permanent or original domicile. ${ }^{17}$

However, Goitein's conclusions do not entirely correspond to reality, ${ }^{18}$ and do not apply to Muslim authors in general, be they geographers, historians or travellers. Terminology - as Lev has pointed out - is often more rigid or schematic than reality: whereas we perceive only the opaque outer shells of these words, when used by medieval authors, their meaning is fluid, full of nuances that would not have been lost on their contemporaries.

\section{Maghāriba and Mashāriqa}

As for the people of the Maghrib, the word maghäriba, according to Muhammad Talbi, firstly

denotes the Arabic-speakers of the Muslim West as opposed to those of the East, known as Mashāriḳa. This division of Arabic-speakers into Mashāriḳa and Maghāariba (...) may be traced from its origins. The frontier between the two major groupings - Muslim Spain included, in spite of its special circumstances and its separate destiny - is still located east of Tripoli, at Lebda, which accounts for the peculiar situation of Libya, constantly divided between its Maghribī and Oriental associations. ${ }^{19}$

Besides the linguistic reference ("the Arabic speakers of the Muslim West as opposed to those of the East"), and the identification of a linguistic "frontier" between Maghrib and Mashriq, what stands out in Talbi's remarks is the fact that these definitions are essentially a matter of mutual perception: "The Arabs, who

17 Goitein 1967, 43-44.

18 See Lev's remarks on this issue (Lev 2017, 67, 69, 71).

19 Talbi, "Maghāriba”, $E I^{2}$, 5: 1159. 
settled on a permanent basis in the West, rapidly became sufficiently Maghribised or Hispanised to appear different from their racial compatriots who had remained in the East". Similarly, in the opening paragraph of the "Mashārika" entry of the second edition of the Encyclopaedia of Islam, Talbi states, "The concern here is rather with the Mashārika who were perceived as such in the West by the Maghāriba". ${ }^{20}$

Indeed, some revealing anecdotes are found in biographical dictionaries by Western Muslim authors. For example, in the Tartīb al-madārik, al-Qāọī 'Iyāḍ (d. $544 \mathrm{H} / 1149 \mathrm{CE}$ ) describes how certain maghäriba living in the first two centuries of Islam were seen by their fellow Muslims in the East during their journey in search of knowledge. One such Westerner is the Tunisian of Persian origin Abū Muhammad Ibn Farrūkh - a student of both Abū Ḥanīfa and Mālik b. Anas (d. 179 H/795 CE), who called him "the faqīh of the Maghrib”. According to al-Qāḍi 'Iyāḍ, he was scorned (izdarāhu) by Zufar b. al-Hudhayl (d. 158 H/775 CE), one of Abū Hanīfa's most important disciples, ${ }^{21}$ on account of his Maghribi demeanour (li-l-maghribiyya). ${ }^{22}$ However, Ibn Farrūkh ultimately got the better of Ibn Hudhayl (qata'ahu bi-l-hujja) in a dispute, and the latter was reproached by the master. Another is the famous Asad b. al-Furāt (d. 213 H/828 CE), who would become one of the most eminent jurists of Kairouan. During his apprenticeship in Medina, Mālik b. Anas reportedly allowed him to attend his lectures within the group of Egyptian students, because the teacher had noticed "his thirst for knowledge" (li-raghbatihi fi al-'ilm), although initially, being a Maghribi, he had had to attend the group of the 'ämma, or common folk. Mālik's full admissions hierarchy, in fact, was as follows: first the Medinese, then the Egyptians, and lastly, ordinary students, the 'âmma. ${ }^{23}$ As Talbi observes, "Peu importe que ces anecdotes soient vraies ou fausses: l'esprit qu'elles traduisent est authentique”. ${ }^{24}$

20 Talbi, "Mashāriḳa”, $E I^{2}$, 6: 712. Italics mine.

21 On this little-known figure and his doctrines, see Cilardo 2008. Although Zufar b. al-Hudhayl was an important disciple of Abū Ḥanīfa, it was Abū Yūsuf and al-Shaybānī who would come to be regarded as the master's two main companions (Heffening/Schacht, "Ḥanafiyya”, $E I^{2}, 3: 162-$ 164.

22 Talbi 1968, 44. For the entire biography of Abū Muhammad 'Abd Allāh b. Farrūkh al-Fārisī in Tartīb al-madārik by al-Qāọī 'Iyāọ,, see Talbi 1968, 40-51. Born in al-Andalus in 115 H/733 CE, he eventually settled in Kairouan. He made two study trips to the East and died in Egypt on the way back from his pilgrimage (Talbi 1968, 50-51). See also al-Mālikī, Riyāạ al-nufūs (1994), 176187, where the above-mentioned episode is found in slightly more detail (al-Mālikī, Riyāẹ alnufūs [1994], 181).

23 Talbi 1968, 53 (full biography 52-70).

24 Talbi 1966, 20: "It is of little importance whether these anecdotes be true or false: the spirit which they express is authentic". 
According to Talbi, the examples show that the Maghrib at the very least had an inferiority complex vis-à-vis the Mashriq, a fact that would lead the Andalusi poet Ibn Bassām in the 6th/12th century to write indignantly in his Dhakhïra: "The people of our lands are eager to ape the Orientals...". ${ }^{25}$

In addition to their presence in biographical dictionaries - of which we have seen only a glimpse, as it is a field still to be systematically explored - as well as in sources such as the Geniza commercial documents, ${ }^{26}$ the maghäriba also show up in geographical and historiographical texts in reference to the military. Lastly, customs, linguistic peculiarities, and ordinary people's devotional practices are mainly to be found in travelogues.

As for the military, historical accounts of the Samarra period make repeated references to a regiment of soldiers called the Maghāriba. ${ }^{27}$ The establishment of the regiment seems to date back to $210 \mathrm{~s} \mathrm{H} / 830$ s $\mathrm{CE}$, late in the reign of alMa'mūn's (r. 197-218 H/813-833 CE). Al-Ya'qūbì (d. ca. 292 H/905 CE) in the section of his Kitāb al-Buldān dedicated to Samarra's topography, states that the area inhabited by the Maghāriba was among the first neighbourhoods created by alMu'tașim (r. 218-227 H/833-842 CE) in his new capital, Samarra. ${ }^{28}$ But who were the soldiers who constituted this Maghäriba corps? In a passage concerning alMu'țasim's campaign against the Byzantine city of Amorium, al-Ṭabarī (d. $310 \mathrm{H} /$ 923 CE) says: "On the third day the battle was fought by the Commander of the Faithful's own troops in particular, together with the Maghāribah and Turks”. ${ }^{29}$ As noted by Bosworth, the sources give little exact information about the ethnic or local origins of these "Westerners", in contrast to the detailed information on the Khorasanians and Transoxianans. ${ }^{30}$ Different hypotheses have been suggested: either they were Berbers from the Maghrib ${ }^{31}$ or it was an ethnically mixed regiment: Arab tribes from the Delta region of Egypt, Berbers from North Africa,

25 Talbi, "Maghāriba”, $E I^{2}$, 5: 1159.

26 In Muslim geographical works commerce is mostly referred to as an exchange between regions, Maghrib and Mashriq, rather than between the inhabitants of these regions.

27 The main sources are al-Ya'qūbī, al-Ṭabarī and al-Mas' ūdī. See Gordon 2001, 37-38; Kennedy 2001, 119, 125-126. According to al-Ya'qūbī, al-Buldān (1892), 263, together with Turkish troops and those from Ferghana and Khorasan, in Samarra there were also the Maghāriba, "who were granted lots near the river port on the Tigris" (Kennedy 2001, 119).

28 Gordon 2001, 38. More precisely, al-Ya'qūbī, al-Buldān (1892), 263, states that "The place known as al-Azlakh, which was where the Maghāriba foot-soldiers (al-rajjāla al-maghāriba) lived, was one of the first parts of Samarra to be laid out" (al-Ya'qūbī, Works [2018], 1: 97).

29 Al-Ṭabarī, History (1991), 113.

30 Al-Ṭabarī, History (1991), 113, n. 317.

31 Talbi 1986, 1160. 
and possibly blacks brought as slaves from East Africa. ${ }^{32}$ However, as pointed out by Gordon, the only specific reference to the origin of the Maghäriba troops, that of al-Mas' 'ùdī (d. 345 H/956 CE), associates them solely with the Hawf (Delta region): "(Al-Mu'tașim) had shaped/trained (iștana' $a$ ) a group from the two 'districts' of Egypt (min hawfay Mișr), (that is) from the 'district' of Yemen, and from the 'district' of Qays. He called them the Maghäriba". ${ }^{33}$ In all likelihood, according to both Gordon and Kennedy, it was a corps made up of prisoners captured by Abū Ishāq, the future caliph al-Mu'tașim, when he was sent to Egypt by his brother al-Ma'mūn to suppress unrest and bring the province firmly under the caliph's control. ${ }^{34}$

Thus, these "Westerners", who made up an important corps in the army of Samarra, ${ }^{35}$ where they had their own estates, were in all likelihood Arabs from the Delta region (Hawf), "not descendants of the original conquerors, but offspring of later immigrants who had been moved from Syria in Umayyad times". ${ }^{36}$ Their name, "the Westerners", in this case has a relative meaning within the context of Samarra's troops, most of whom were Turks or soldiers from distant Ferghana in modern-day Uzbekistan. By comparison, troops from Egypt were certainly "Westerners”.

The term Maghäriba, then, as employed in 3rd-4th/9th-10th-century Eastern historiographical sources with reference to this 'Abbāsid army corps, seems to have been used just as loosely as in the Geniza documents with reference to the Maghāriba merchants of the Mediterranean area between the 5th/11th century and the 6 th/12th century.

32 Al-Ṭabarī, History (1991), 113, n. 317. According to Gordon 2001, 38, this is not a very plausible hypothesis, since mixing different ethnic groups in one regiment was rare in this period.

33 Gordon 2001, 38. The region to the east of the eastern branch of the Nile was called al-Hawf, the central region of the Delta was al-Riff, while the land to the west of the western arm was called al-Buhayra, and later al-Hawf al-Gharbī (see Kramers 1995, 39). The term “districts”, in Gordon's translation of the passage, refers therefore to the two Hawfs, the two areas of the Egyptian desert, to the east and west respectively of the Nile Delta, where Arab tribes, from Qays and Yemen, had settled. In this passage Al-Mas 'ūdī reports that al-Mu'tașim had already enrolled military forces of different origins such as Turks, whom he favoured, but also the "Maghribis", as well as soldiers from Khorasan, Ferghana and Ushrūsana, in Baghdad, before Samarra was founded. See al-Mas' ūdī, Prairies (1873), 118.

34 Gordon 2001, 38; Kennedy 2001, 125-126.

35 As for their number, Bosworth refers to al-Bayhaqī’s Kitāb al-Maḥāsin wa-l-masāwī, written in the first decades of the 4th/10th century, where "it is mentioned, on the authority of the $r \bar{a} w \bar{\imath}$ Ḥamdūn b. Ismāî̀l, that 4,000 Maghāribah were involved in a ceremonial parade on the occasion of the 'îd" (al-Tabarī, History [1991], 113, n. 317).

36 Kennedy 2001, 125. 
However, a small but telling detail in a passage from al-Tabarī’s History reveals something more: the contemptuous way in which the "Easterners" regarded these "Westerners”. It is the passage where al-Tabarī reports how Mazyār, rebel lord of Tabaristan, denounced general Afshin for having instigated his revolt against the caliph and having proposed an alliance between them. In a list of the military forces that the caliph al-Mu'tașim would have had at his disposal to combat them, three groups are mentioned, "the Arabs, the Maghariba, and the Turks". Quoted as direct speech, the following comment is reported: "As for the flies" - meaning the Maghäriba - "they are only a handful". ${ }^{37}$ It is an interesting passage both in terms of al-Afshinn's disdainful remark about the Maghäriba - could the term "flies" refer to their swarthy complexion, as Bosworth suggests $^{38}$, or, perhaps more likely, to their presence being considered annoying, however harmless? - as well as for the fact that al-Tabarī, himself a Persian, perfectly understands who the expression hints at and feels the need to explain it to the reader.

It is known, however, that it would be in the Fātimid context that the $M a$ ghāriba were to enjoy a leading role in the military, first in Ifrīqiya, and then well into the Egyptian period. The Kutāma Berbers supplied the major contingents of the Fātimid army, and it is in Cairo that the antagonism between Maghāriba and Mashāriqa (which apparently predates the Fātimid conquest) ${ }^{39}$ became particularly violent, starting with the passage from al-'Azīz's caliphate (r. 365-386 H/ 975-996 CE) to al-Ḥākim's (r. 386-411 H/996-1021 CE). The Westerners, as Walker points out, "comprised Arabs as well as Berbers, true Maghribis from Ifrīqiya along with the Șiqillis (and possibly Andalusis) - that is any one from west of Egypt”. ${ }^{40}$ They contrasted with the Mashāriqa, mainly Turks and Daylamis, who al-'Azīz had started importing in droves to create his own regiments of professional soldiers from the East, and to whom he offered prominent positions in the

37 Al-Ṭabarī, History (1991), 191. Italics mine. Various degrees of contempt are also expressed in what is said about the other two groups: "As for the Arab, he is like a dog; i will throw him a scrap of food and then beat his brains out with a mace [...] As for the sons of devils - meaning the Turks - it is only a short period of time before they have loosed off their arrows, and then the cavalry [...] will destroy them to the last man".

38 Al-Țabarī, History (1991), 191, n. 548.

39 Brett 2001, 161, traces back to the year 323 H/935 CE the rivalry between Mashäriqa (Turks) and Maghäriba, according to him "probably a combination of Berber and Black squadrons and regiments".

40 Walker 2008, 48. 
army as well as in the government. It is in fact during al-'Azīz's reign that "the standing of the Kutāma steadily diminished and that of the Turk rose”. ${ }^{41}$

Egypt is therefore the place where the Western and Eastern military forces mainly Berbers and Turks, who took turns enjoying the Fātimids' favour - faced off, struggling for power as of the first half of the 4th/10th century, which fits its characterization, across many writings and contexts, as a watershed between East and West.

And this leads us back to the analysis of the terminological pair Mashriq/Maghrib, first of all in geographical works, where the two terms arose as descriptive categories starting in the late 3rd/9th century.

\section{Maghrib and Mashriq in Eastern geographical texts: al-Ya'qūbī's view (late 3rd/9th century)}

As Claude Cahen observed five decades ago in an article full of both insight and unanswered questions, ${ }^{42}$ Eastern Muslim historians almost completely ignored the part of the Islamic world known as the Maghrib - roughly the region west of Egypt $^{43}$ - until Ibn al-Athīr (d. $630 \mathrm{H} / 1233 \mathrm{CE}$ ). Unlike his predecessors, he devoted to it a considerable part of his "universal” history al-Kāmil fì al-ta'rīkh (which covers events until $628 \mathrm{H} / 1231 \mathrm{CE}$ ), having got hold of enough material “pour écrire, sur l'histoire aussi bien du Maghreb ou de l'Espagne que de l'Asie Centrale, des chapitres d'une qualité qui en fait pour nous mêmes une source à consulter à égalité des sources autochtones". ${ }^{44}$

41 Walker 2008, 49.

42 Cahen 1970, 41-49.

43 In addition to Cahen's remarks on the Arab historians' scant interest in the events related to the territories west of Egypt, it is also worth mentioning the following observation by Goodchild: "The Arab documentary sources, relatively detailed in their account of the conquest of Egypt, dry up almost completely once the army of 'Amr ibn al-Aasi moved westward from the Delta". Even the fullest and most reliable account of the expedition, that of Ibn 'Abd al-Hakam, after stating that the Luwāta Berbers had long occupied Anțābulus (Pentapolis) or Barqa, says no more than: "'Amr ibn el-Aasi now entered the land with his horsemen and reached Barka, with whose inhabitants he made a treaty" (Goodchild 1976, 255).

44 Cahen 1970, 47. Cahen's evaluation of Ibn al-Athïr's ability to write "a number of chapters of such quality to constitute for us a source as valuable as local ones" about the history of the Maghrib and al-Andalus, as well as of Central Asia, must now be compared with Luis Molina's analysis of Ibn al-Athïr's work and his use of historical sources from al-Andalus. See Molina 2020. I am grateful to the author for providing me with a copy of his paper before publication. 
Predictably, al-Baladhurī (d. ca. 279 H/892 CE) hardly says anything in his Futūh al-buldān apart from the events of the conquest. Likewise, Egyptian historian Ibn 'Abd al-Hakam (d. 257 H/871 CE) dedicates three quarters of his work on the Arab conquests in North Africa to Egypt. Even al-Ṭabarī, as Cahen observes, in the thousands of pages of his $\mathrm{Ta}^{\prime} \mathrm{ri} k \mathrm{k}$, did not dedicate more than a few lines to the events of the West, "dont les plus importants lui sont inconnus ou indifférents". ${ }^{45}$ Were the events of the West unknown to him, or else uninteresting?

With reference to al-Andalus, Luis Molina ${ }^{46}$ has recently addressed the question of Eastern historians' silence about the events of the Islamic West after the conquest, by focusing on the circulation of information on the Iberian peninsula among medieval historians from the Islamic East and their use of works written by authors from al-Andalus. The answer, supported by precise documentation, suggests that during the early stage - until the 4th/10th century - there was indeed scant information and interest, limited exclusively to the events of the conquest. Subsequent events are almost completely ignored, possibly for ideological reasons. In certain cases, there are grounds to believe that Eastern historians' silence responded to a conscious decision. ${ }^{47}$ A second stage - from the early 7th/13th century onwards - is marked instead, according to Molina, by a kind of passive attitude on the part of Eastern historians, who, rather than conduct research of their own, seem content to draw directly on Andalusi sources, by then circulating in the East, and which they simply include in their own works.

However, going back to Cahen's remarks, by contrast with historians, some Eastern geographers between the late 3rd/9th century and the 4th/10th century had already provided well-documented descriptions of the Maghrib region. From this point of view, an especially enigmatic figure is historian and geographer al-

45 Cahen 1970, 43: "the most important of which (Western events) are unknown or uninteresting to him”.

46 Molina 2020.

47 It seems to be the case with al-Mas' $\overline{\text { uid }}$, who, as Luis Molina observes, in the geographical section of his encyclopaedic work Murūj al-dhahab gives many reports not only referring to the conquest of al-Andalus, but also to historical events up until the time his work was written. However, in the second part of the Murūj, a general history of the Islamic world, there is no mention of al-Andalus at all. According to Molina, this indicates that al-Mas' ūdī was sufficiently informed about the history of al-Andalus, and if he did not include it in the historical section of the Murüj this was due to a conscious decision (Molina 2020). This, in turn, poses another question: why such a difference between the historian and the geographer? A problem that, as we will see, also concerns another Eastern author, al-Ya'qūbì, and which perhaps has to do with the mental boundaries established by Muslim authors between different fields of knowledge. With reference to al-Ṭabarī, see also Calasso 2017, 26. 
Ya 'qū $\overline{b i}^{48}$, who, as Cahen has pointed out, “comme géographe, décrit avec détail l'Afrique du Nord, où il a été, et qui, comme historien, ne connait plus rien en dehors de l'Orient". ${ }^{49}$

Thus it is perhaps worth taking as our starting point al-Ya'qūbì - whose Kitāb al-Buldān was composed in the final decade of the 3rd/9th century ${ }^{50}$ - in order to identify the path toward the establishment of a boundary between Mashriq and Maghrib in the writings of Muslim geographers.

Al-Ya'qūbì's perspective - that of a civil servant and member of the cosmopolitan 'Abbāsid élite - is resolutely Iraq-centric, openly stating that this region is "the centre of the world and the navel of the earth" (wașat al-dunyā wa-surrat al-arḍ), in the same way as Baghdad is "the centre of Iraq" (wașat al- Irāq), and a city that has no peer, "neither to the east nor to the west of the earth" (allatì laysa lahā nazir fì mashāriq al-arḍ wa-maghāribihi). Thus, in the words of Matthew Gordon, "the Buldān is properly described as an 'imperial' digest". ${ }^{51}$ The description of Baghdad, the original 'Abbāsid capital, is followed by that of Samarra, the 'Abbāsid capital for much of the 3rd/9th century, although by that time it had nearly reached the end of its history as imperial hub. Al-Ya'qūbī could not be clearer about this, stating, "We began with them because they are the royal cities and the seats of the caliphate...".52 Around this centre, the other Islamic regions (al-Ya 'qūbì still does not use the expression mamlakat al-islām) are then divided into four "quarters" ( $r u b$ ', pl. arb $\bar{a}^{\prime}$ ), the first being the eastern one, al-Mashriq, from Jibal to Khorasan, to Transoxiana. Next follows the southern $r u b^{\prime}$ : lower Iraq, Medina, Mecca, Yemen. The third $r u b^{\prime}$ 'is the northern one and, finally, the fourth is the western one, al-Maghrib. Unfortunately, the work we have at our disposal is incomplete. As explained by Everett K. Rowson, “A very large lacuna has deprived us of much of the Southern quarter (and part of what survives is

48 Our best source on al-Ya 'qūbī's life is Yāqūt's entry. However, the date of Ibn Wādihh's death as given by Yāqūt, $284 \mathrm{H} / 897 \mathrm{CE}$, is now considered untenable and should be moved to $295 \mathrm{H} / 908$ CE. See Anthony/Gordon 2018, 12-13.

49 Cahen 1970, 43: "As a geographer, he describes in detail North Africa, where he has been, while as a historian he seemingly knows nothing but the East”. Gérard Lecomte, in a brief article, pointed out that also Ibn Qutayba (d. 276 H/889 CE), the great Sunnī polymath and al-Ya'qūbī's contemporary, in his Kitāb al-Ma ârif, only mentions Ifrīqiya twice, in reference to the conquests, without saying anything about the founding of Kairouan, and writes but a few words about the West, both in the Umayyad and the 'Abbāsid periods, apart from reporting the arrival of 'Abd alRaḥmān - grandson of the caliph Hishām - who took over al-Andalus (Lecomte 1957, 253-255). 50 He himself says that he wrote the Kitā b al-Buldān fifty-five years after Samarra's foundation (221 H/836 CE), hence around 276 H/889 CE. See al-Ya'qūbī, Works (2018), 1: 101.

51 Gordon 2018, 6.

52 Al-Ya'qūbī, Works (2018), 1: 102. 
mislabelled the Northern quarter), all of the Northern quarter, and the first part of the Western quarter". ${ }^{3}$

The route westward starts from Aleppo in northern Syria, passing through Homs, Damascus, Jordan, Palestine, Lower and Upper Egypt, and even Nubia, the land of gold and emerald mines. Following this itinerary there is a paragraph describing the route from Egypt to Mecca, for the benefit of pilgrims, after which the author at last moves on to the Maghrib proper: "from Egypt to Barqa to alMaghrib al-aqșā (the far West)". After describing the cities of Ifrīqiya, a short section is dedicated to al-Andalus, along with directions on how to reach it from Kairouan. The account then starts again from Tahert (in present-day Algeria), nicknamed "the Iraq of the Maghrib", and closes with Sijilmāsa and al-Sūs alAqșā (Morocco)..$^{54}$

Thus, in al-Ya'qūbì's five-area division - a centre, Iraq, surrounded by four $a r b \bar{a}^{c}$ - the attention paid to the Maghrib is indeed limited. No more than fifteen pages are dedicated to the region, including al-Andalus, although it is also true that the information provided is fairly accurate ${ }^{55}$, in particular concerning the itineraries from place to place and the inhabitants. Here, the Maghrib region is simply the westernmost part of the "western $r u b$ " " of the Islamic lands, taken to include Syria and Egypt as well. There is still no direct comparison with the Mashriq, nor any indication of a boundary separating the two. There is likewise no explicit hierarchy between the East and the West; the Maghrib is the last region to be described, but this is only logical since in the structure of the work the four $a r b \bar{a}^{\prime}$ are described from east to west.

By contrast, a hierarchical view is openly expressed in a tradition reported by a contemporary of al-Ya'qūbī, Iranian geographer Ibn al-Faqīh, in his Kitāb alBuldān (written ca. $290 \mathrm{H} / 903 \mathrm{CE}$ ). The same tradition is also found, in a slightly modified yet significantly different version, at the beginning of the Egyptian historian Ibn 'Abd al-Hakam's (d. 257 H/871 CE) Futūḥ Miṣr. ${ }^{56}$ According to this tradition, the earth was created in the shape of a bird, with each of the five main parts of its body corresponding to a region, or a group of regions, of the inhabited world: the head, in Ibn al-Faqih's version, corresponds to China, the right wing to India, the left one to the Khazar region, while the chest is Mecca, Hejaz, Syria,

53 Rowson 2018, 26. See also al-Ya'qūbī, Works (2018), 1: 156, n. 484, where De Goeje’s note about this mislabelling - translated from Latin - is reported.

54 Al-Ya'qūbī, al-Buldān (1892), 342-360; al-Ya'qūbī, Works (2018), 1: 178-198.

55 For what concerns the valuable information provided on toponyms, ports and fortifications, as well as water supplies, agricultural products and mineral resources in the section devoted to the Maghrib in al-Ya'qūbī's work, see Manzano 2017.

56 Ibn 'Abd al-Ḥakam, Futūḥ Miṣr (1922), 1. 
Iraq and Egypt. Finally, the tail corresponds to the region stretching from Dhāt al-Ḥumām (near Alexandria in Egypt) "to the land of the setting sun" (ilā maghrib al-shams), concluding with the remark that "the worst part of a bird is the tail" (wa-l-sharru mā fi al-țayr al-dhanab). ${ }^{57}$ However, according to the version reported by Ibn 'Abd al-Ḥakam on the authority of 'Abd Allāh b. 'Amr b. al-'Āṣ - son of the Muslim conqueror of Egypt - the bird's head corresponds to Mecca, Medina and Yemen, while Egypt and Syria are its chest, Iraq and Sind the wings, and the Maghrib the tail. As can be seen, of the two variants of the tradition - whose origins are unknown - the one quoted by Ibn al-Faqih refers to the whole world, identifying China as the bird's head and placing Arabia, Syria, Iraq and Egypt in the centre. That of the Egyptian historian, on the other hand, limited to Islamic countries, gives pride of place to Arabia,${ }^{58}$ but chooses Egypt and Syria to occupy the centre, the chest of the bird, placing Iraq on the right wing, and Sind on the left. Both accounts, however, leave the worst part - the tail - to the Maghrib.

A similar hierarchical view does not have any explicit correspondence in alYa'qūbì's work. What is interesting, rather, is the attention the author devotes to the variety of ethnic components of the Maghrib and the relevant terminology. Of the three political powers unevenly dividing Northern Africa at the time, the Aghlabids of Kairouan, the Rustamids of Tahert and the Idrisids of Fez, alYa'qūbī's survey of the tribes' distribution mostly covers the Tahert area. One of the most significant features that emerges, too, is the fragmentation of the ancient tribal groups. ${ }^{59}$ However, aside from this fragmentation, what draws the geographer's attention is more generally the mix of people who inhabit these territories, even in cities and their suburbs, mainly in Ifrīiya: Arabs, Persians, and 'ajam al-balad, "the non-Arab locals", ${ }^{60}$ among whom he draws further distinctions based on their various places of origin. There are also the Rüm, descendants of the ancient Byzantines who ruled the country before the Arab conquest, as for instance in the city of Barniq, on the Mediterranean coast ("the coast of the Salt Sea"): it is inhabited by people descended from the ancient Romans, who in former times had made up the city's population (wa-ahluhā qawm min abnä' al-rūm al-qudum alladhīna kānū ahlahã qadìman). ${ }^{61}$ Sometimes they are also defined as baqāya al-Rūm, "the remaining Rūm", in all likelihood the descendants of the

57 Antrim 2012, 96, 133.

58 It is still to be established whether, given this symbolic recognition of Arabia, the head or the chest is in fact more important in Ibn 'Abd al-Hakam's mental hierarchy.

59 Marçais 1957, 38.

60 On this autochtonous minority under the Aghlabids, see Bahri 2000, which focuses in particular on their legal and social status as well as the chronology of their Islamization.

61 Al-Ya'qūbī, al-Buldān (1892), 343. 
soldiers and officials of the Byzantine Empire, who had established themselves there two or three centuries earlier. Finally, there are the less easily identifiable Afäriqa, who are distinguished from the Berbers by al-Ya 'qūbī and who, according to Marçais, could essentially be identified by the language they spoke, neither Arabic nor Berber nor Greek, but perhaps the variety of Latin spoken in the ancient Roman province. ${ }^{62}$

The term akhlät, which indicates a "mixture", frequently occurs in this section of his work when referring to the people who inhabit the Maghrib region, who are 'arab, 'ajam and 'ajam al-balad, the latter being the group in which the geographer includes Berbers, Rūm, and Afäriqa. As for the 'ajam, the Eastern non-Arabs, "We can find some individuals coming from Khorasan, Basra and Kufa (akhlāṭ min ahl khurāsān wa-min al-bașra wa-min al-kūfa)", ${ }^{63}$ but above all the 'ajam are represented by the Persians of the Ibāẹi principality of Tahert, which he refers to as the "Iraq of the Maghrib". The term akhlāt is used to characterise the mixture of groups in general - as in the expression akhlät min al-nās ("a mixture of people") when speaking of Tripoli's inhabitants - while Gabes's population is more precisely described as "akhlāt min al-'arab al-'ajam wa-l-barbar" (a mixture of Arabs, Eastern non-Arabs - i.e. Persians - and Berbers) ${ }^{64}$ In Kairouan, the mixture is even more heterogeneous, made up of people from the Quraysh and other Arab tribes, Eastern non-Arabs (Persians) from Khorasan ( $\mathrm{min}$ quraysh wa-min sā'ir buțūn al-'arab (...) wa-bihā așnāf min al-'ajam min ahl khurāsān...) as well as "autochthonous non-Arabs” ('ajam min 'ajam al-balad), Berbers and Rūm. ${ }^{65}$ As for the cities of Qasțiliya, "the inhabitants of these cities are non-Arabs descending from the ancient Rūm, Afāriqa and Berbers” (ahl hādhihi al-mudun qawm 'ajam min al-rūm al-qudum wa-l-afāriqa wa-l-barbar); ${ }^{66}$ and in the Zab region, a ten-day journey from Kairouan, "the mixture is made up of Quraysh and other Arab tribes of the army, Eastern non-Arabs (Persians), Afāriqa, Rūm (Byzantines) and Berbers" (wa-bihā akhlāṭ min quraysh wa-l- 'arab wa-l-jund wa-l- ‘ajam wa-l-afāriqa wa-l-rūm wa-l-barbar) ${ }^{67}$

Considering that just over ten pages are dedicated to the Maghrib, the concentration of such detailed information on this theme is remarkable. Besides al-

62 Marçais 1957, 41-42, supports this hypothesis with the fact that al-Idrīsi (6th/12th century), a much later author, claims that in Gafsa, which he refers to as "the city of the Afāriqa", "most people still speak the Latin language of Africa” (al-lisān al-latīnī al-afāriqī).

63 Al-Ya'qūbì, al-Buldān (1892), 345.

64 Al-Ya'qūbī, al-Buldān (1892), 347.

65 Al-Ya'qūbī, al-Buldān (1892), 348.

66 Al-Ya'qūbī, al-Buldān (1892), 350.

67 Al-Ya'qūbī, al-Buldān (1892), 350. 
Ya 'qūbì's attention to the heterogeneous ethnic composition of the Maghribi population, we can also perceive his concern with the temporal stratification of its different components, in a word, with the history of these regions that witnessed in different periods the overlapping of Berbers, Romans, Byzantines, Arabs and Persians. The recurrence of formulaic expressions such as al-'ajam al-qudum, alrūm al-qudum, al-barbar al-qudum, al-jund al-qudum, al-afāriqa al-qudum, however imprecise, evokes a past tied to this ethnic diversity.

Also in the section devoted to the eastern $r u b^{c}$ - particularly the area from Nahrawan to the main cities of northern Iran (Dinawar, Qazvin, Nihavand, Isfahan, Rayy, Nishapur, Sarakhs) - al-Ya 'qūbī points out on almost every page that the inhabitants are a mixture of Arabs and non-Arabs, the latter mainly called 'ajam, and only three times by their own name: Persians (al-Furs) ${ }^{68}$ What is worth noting with reference to the Maghrib is that when specifying what the "mixture" is composed of, next to the well-known, longstanding dichotomy 'arab/'ajam, a new entity appears, that of 'ajam al-balad, the autochthonous non-Arabs (or nonArabic speakers), i.e. the non-Arabs of the western regions, a category which, according to al-Ya'qūbì, only partially overlaps with the Berbers. ${ }^{69}$ This new component, in symmetrical opposition to that of the Eastern 'ajam, is now given recognition.

\section{Al-Mashriq and al-Maghrib in mamlakat al- islām: the contrasting views of Ibn Ḥawqal and al-Muqaddasī (4th/10th century)}

\subsection{Ibn Hawqal's Maghrib as the land of the Berbers}

The first emergence of al-Maghrib as a distinct reality from al-Mashriq in mamlakat al-islām is to be found in the works of the 4th/10th-century Eastern geographers Ibn Hawqal and al-Muqaddasī, each of whom nevertheless assesses this reality in different terms. It was still not so in the work of their predecessor - and Ibn Ḥawqal's teacher - al-Ișțakhrī, a native of Fārs, whose Kitāb Masālik almamālik was written in the mid-4th/10th century. In the whole of his work, Iran

68 Al-Ya'qūbī, Works (2018), 1: 103-114; al-Buldān (1892), 270-279. Three times does the author mention also the Kurds among the non-Arabs (al-Ya'qūbī, Works [2018], 1: 103, 104, 109).

69 See Marçais 1957, 39-42. 
- and in particular the author's native region of Fārs - is placed at the forefront and given ample space, even though the Arabian peninsula - diyār al-'arabcomes first in the text, followed by the description of the surrounding bahr Fāris, by which the author means not just the Persian Gulf but the Indian Ocean as a whole. The ensuing countries are then described as an uninterrupted sequence from west to east, although there is no particular stress on an East/West boundary. ${ }^{70}$ It is only with Ibn Hawqal and al-Muqaddasī, the two eminent successors of al-Ișțakhrī in the 4th/10th century, that the Maghrib gains visibility in the general framework of mamlakat al-islām.

In the eyes of Eastern Muslim geographers, Egypt seems to be the last region of the East bordering the Maghrib, or rather, as the Palestinian al-Muqaddasi puts it - specifically referring to al-Fusțāt - it is "the point of intersection between alMaghrib and the lands of the Arabs (fașl bayna al-Maghrib wa-diyār al- 'arab)", ,1 seemingly implying that the West is an ethnically different reality; does he mean to say that it is the land of the Berbers? The comparison between Ibn Hawqal and al-Muqaddasī, as we will see below, shows significant differences in this respect and others.

The first detailed description of the medieval Maghrib can be ascribed to Iraqi geographer Ibn Hawqal (fl. second half of the 4th/10th century); ${ }^{72}$ as Garcin wrote in his important 1983 article on the subject, "Due à un oriental, elle a marqué la place désormais acquise par ce pays dans l'empire de l'Islam". ${ }^{73}$

Thus, the 4th/10th century officially marks the emergence of the binary division of "the Islamic world" into Mashriq and Maghrib. Whereas the dār alislām/dār al-harb dichotomy was conceived as such by Sunnī Muslim jurists, the mashriq/maghrib binary as it emerged in these 4th/10th-century geographical texts was the result of Eastern authors' "acknowledgment" of the Western region

70 As for the part on the Maghrib in al-Iștakhrī’s work, André Miquel has highlighted its value, even though in terms of size and quality of information it is not comparable to the chapter Ibn Hawqal dedicates to it. The Maghrib is seen by al-Isțakhrī as divided into two halves, an eastern and a western one, the latter coinciding with al-Andalus. Moreover, as Miquel points out, the things al-Isțakhrī leaves out of the chapter prove to be equally interesting, for instance Sicily, which he does not perceive as part of the Maghrib (Miquel 1973, 231-239).

71 Al-Muqaddasī, Ahssan al-taqāsīm (1877), 197. In translating faṣl as "point of intersection” I have followed Miquel 1972, 115-116.

72 The dates of his birth and death are unknown. What is known is that starting in $331 \mathrm{H} / 943 \mathrm{CE}$ he undertook a series of journeys through various regions of the Islamic world. His trail is lost after $362 \mathrm{H} / 973 \mathrm{CE}$, when he travelled to Sicily (Miquel, “Ibn Ḥawḳal”, $E I^{2}$ ).

73 Garcin 1983, 77: "Being the work of an Easterner, it designated the position this land had acquired by then within the Islamic Empire”. 
of the Muslim territories, beginning with Ibn Hawqal, who devotes a lengthy chapter to "al-maghrib". This name designates a region with precise boundaries, starting in the vicinity of Barqa and stretching westward over the whole of North Africa, also including al-Andalus and Sicily. Mainly inhabited by Berber populations, this region, whose principal activity reported is trade, includes many cities whose names and features are duly indicated and described, along with the roads that connect them. The East/West dichotomy remains implicit, and yet clearly perceptible.

Al-mashriq, the eastern part of the Muslim territories, is not mentioned in Ibn Hawqal's work by this name, nor are its borders defined. However, the organization of the material in his Kitāb Șūrat al-arḍ reveals the hierarchy the author has in mind: following al-Ișțakhrī, Ibn Hawqal starts off by describing diyār al'arab - by which he means specifically Arabia - "because Mecca, that is the qibla, is found there, and because it is the land of the Arabs, their homeland, which they inhabit without having shared it with any other peoples (balad al'arab wa-awțānuhum lam yashrakhum fi suknāhā ghayruhum)". ${ }^{74}$ What follows, as a geographical corollary, is a section devoted to the Indian Ocean (baḥr Fāris), due to the fact that it surrounds Arabia on three sides. However, after this due tribute to the cradle of Islam, the author goes on to describe all the Muslim territories from west to east: first the Maghrib, which includes al-Andalus and Sicily; ${ }^{75}$ then Egypt, which therefore is not part of the Maghrib, yet is not explicitly defined as part of the Mashriq either; next Syria, followed by a section devoted to the Mediterranean. The author then turns to Jazira and Iraq, which according to him is the best province, blessed with all possible advantages, yet so well known that he declares there is no need to dwell on it for long. Then he moves on to the northwestern regions of the eastern Muslim lands - Armenia, Azerbaijan and Jibal followed by the lands of the north of Iran, Daylam and Tabaristan. An interlude

74 Ibn Ḥawqal, Șūrat al-arḍ (1938-39), 18. Ibn Ḥawqal's description of Arabia almost seems to represent the opposite of that of the Maghrib given more than fifty years before by al-Ya'qūbī, who highlights the heterogeneous ethnic composition which characterises the western regions of the lands of Islam, as well as those of north-eastern Iran. Could we already see behind alYa'qūbī's stressing this mixture of peoples, an implicit comparison with Arabia and its ethnic identity?

75 Ibn Ḥawqal, Șūrat al-ard (1938-39), 131. Ibn Ḥawqal, after having described North Africa as well as al-Andalus and Sicily, concludes the section with these words: "this is the description of the Maghrib in its entirety” (wa-hādhihi jumal min awșāf al-maghrib). Already in a previous passage, he indicates that al-Andalus is part of the Maghrib (wa-hiya fi jumlat al-maghrib). See Ibn Ḥawqal, Șūrat al-arḍ (1938-39), 62. 
is then devoted to the Caspian Sea (bahr al-Khazar), before going back to Khorasan and the deserts of Fārs. Lastly, the author turns to Sijistan, Khorasan and Transoxiana.

It is true that, on the whole, Ibn Hawqal dedicates the majority of his work to the region of Iran, as pointed out by Gabriel Martinez-Gros. ${ }^{76}$ It is also true that in the initial part of his work, in which he provides the general coordinates of mamlakat al-islām, including its overall length, Ibn Hawqal specifies: "When mentioning the length of the Islamic territories (țūl al-islām) I have neglected [to consider] the border of the Maghrib up to al-Andalus because it is like the sleeve of a garment (li-annahu ka-l-kumm fi al-thawb)". ${ }^{77}$ However despite this apparently unflattering consideration of the westernmost territories of Islam (but is "the sleeve of a garment" the whole of the Maghrib or only al-Andalus?), the number and the quality of the pages dedicated to the description of the western region, as well as the vast amount of information given, shows that in Ibn Hawqal's view it is far from being a secondary, remote periphery of mamlakat al-islām. It is also worth mentioning a passage, within the section dedicated to the Mediterranean, in which the Byzantine territories (bilād al-Rūm) and the Maghrib are compared: "the countries of the Rūm are far from possessing the means and the strength at the Maghrib's disposal (lā yuqāribu asbāb al-Maghrib wa-ḥaddahu) [...]. I have already mentioned the Berber tribes inhabiting its deserts [...] and I have stressed the strength, the vigour, the resistance and the energy they possess (quwwa wal-jalad wa-mahalluhum fi al-ba's wa-l-shidda)". ${ }^{78}$

Ibn Hawqal, as stated in his introduction, intended to compile a more complete work than his predecessors, setting himself the goal of studying the reasons behind the differences between countries: their customs, their culture and the ways and paths they adopt (ilā kayfiyyat al-bayn bayna al-mamālik fí al-siyar wal-haqā' iq wa-tabāyunihim fí al-madhāhib wa-l-țarā'iq).${ }^{79}$ What makes the Maghrib different from the other regions of the Muslim world is the Fātimid Caliphate, whose leader Ibn Hawqal mainly refers to as the "Lord of the Maghrib” (șāhib al-

76 Martinez-Gros 1998, 323.

77 Ibn Ḥawqal, Șūrat al-arḍ (1938-39), 17.

78 Ibn Hawqal, Șūrat al-arḍ (1938-39), 200.

79 Garcin 1983, 78; Ibn Ḥawqal, Șūrat al-arḍ (1938-39), 3, 1.9. 
maghrib), and whose influence he sees as pervasive. ${ }^{80}$ The intricate textual question of the different, contrasting versions of Ibn Hawqal's work ${ }^{81}$ - including "pro-Fāṭimid" or "anti-Fāṭimid" passages - which has reemerged with the recent discovery of a manuscript that would appear to contain its earliest version, ${ }^{82}$ continues nevertheless to be unresolved. Without trying at all costs to ascribe to the author an exclusive and unanbiguous political allegiance, it is undeniable that he felt the presence of the Fātimids in this area was significant, and the fact remains that the success of the Fātimids clearly hinged on the Maghrib. This, in Garcin's words, was the main reason why "le Maghreb a fait une si belle entrée dans la littérature géographique". ${ }^{83}$ And here is the second and most important distinguishing feature of the Western lands: Ibn Hawqal's Maghrib is the land of a people, the Berbers. There is hardly a page that does not mention them, whether by name, or in terms of their presence in different areas; their farming, animal husbandry or trade activities; or their customs, whether to praise or criticize them. Moreover, toward the end of the chapter on the Maghrib the amount of information on them increases, including a summary in which Ibn Hawqal provides the reader with the names of their tribes and the clans of which each tribe is composed.

Among the "new" peoples, so to speak, that Ibn Hawqal discovered during his travels, he particularly appreciated the inhabitants of Khorasan and Transoxiana in the East and the Berbers in the West, and thought that all three groups shared a set of common traits. ${ }^{84}$ He saw the Berbers as a great people capable of

80 Garcin 1983, 78, n. 11. See Ibn Ḥawqal, Șūrat al-ard (1938-39), 83: "All the region between Ifrīqiya and Tangiers are under the rule of the lord of the Maghrib" (kullu dhālika fi jumlat șāhib al-maghrib); Yūsuf b. Zīrī is called the "deputy of the lord of the Maghrib" (khalîfat șāhib al-maghrib) (Ibn Ḥawqal, Șūrat al-ard [1938-39], 78). The expression is sometimes used in the plural, așhāb al-maghrib (Ibn Ḥawqal, Șūrat al-arḍ [1938-39], 105). In other passages Ibn Ḥawqal refers to the Fāțimid caliph as mawlānā amìr al-mu'minin ("our lord, the commander of the faithful"; Ibn H̦awqal, Șūrat al-ard [1938-39], 72) or mawlānā 'alayhi al-salām (“our lord, peace be upon him”; Ibn H̦awqal, Șūrat al-arḍ [1938-39], 79, 72 in the plural), or also as sulțān al-maghrib (Ibn Hawqal, Șūrat al-ard [1938-39], 75). On the implications of these different denominations, and their presence or absence in the various versions of Ibn Ḥawqal's work, see Benchekroun 2016, 202-205.

81 For a synthetic overview, see Ducène 2017.

82 See Benchekroun 2016.

83 Garcin 1983, 85: "this was the main reason why the Maghrib made such a grand entrance into geographical literature”.

84 See Garcin 1983, 87 about certain Berber tribes' extraordinary ability to find their way in the desert, which he compares to similar reports about the inhabitants of Ferghana, Ushrūsana, Isbijāa and Khwārizm (Ibn Ḥawqal, Șūrat al-arḍ [1938-39], 101-102). 
extraordinary endurance, and so believed that the Fātimids' strength came from having the Berbers at their disposal. ${ }^{85}$ Gone are the akhlāt al-nās or 'ajam al-balad including Rūm and Afäriqa: here the Berber presence is the defining trait of the Maghrib.

Therefore in Ibn Hawqal's work, the main components of the identity of the region called al-Maghrib, and implicitly of the distinction between Mashriq and Maghrib, seem to be, on the one hand, and whatever his position towards them may have been, the Ismāîlì Fāṭimids - the heterodox political-religious power challenging the mainstream or "orthodox" Islam of the 'Abbāsid Caliphate - and, on the other, the region's non-Arab prevailing ethnic group, the Berbers, to whom Ibn Hawqal credits the Fāṭimids' success.

\subsection{Al-Muqaddasī's Maghrib, the far-off western periphery of the Arab regions}

The topic is organized altogether differently by Palestinian geographer al-Muqaddasī, a contemporary of Ibn Hawqal, ${ }^{86}$ who divides mamlakat al-islām into two

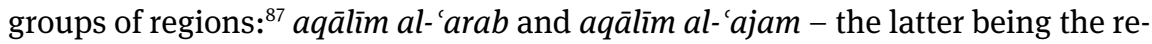
gions of the Eastern non-Arabs (Persians and others) - for a total of 14 aqālìm, 6 Arab and 8 non-Arab. In this division, the Maghrib, made up of North Africa, alAndalus and Sicily, is listed as the sixth and last Arab iqlim after Arabia, Iraq, Aqūr (Jazira), Syria, and Egypt. In order of appearance in the text, the eight aqālìm al-'ajam are: al-Mashriq, Daylam, al-Rihāb, ${ }^{88}$ Jibāl, Khūzistān, Fārs, Kirmān and Sind, ${ }^{89}$ "al-Mashriq" being just the easternmost reaches of these aqālìm, which al-Muqaddasī further divides into two parts (jānibān), situated on either

85 Garcin 1983, 87. This trait of Ibn Hawqal's in a way anticipates Ibn Khaldūn's vision of a new ethnic group, a new 'așabiyya, able to defend and once again give vigour to the threatened Islamic world: a new ethnic group which the latter, at the end of the 8th/14th century, would instead identify with a people of Eastern origin, the Mamlūk Turks, at the time lords of Egypt.

86 The year of his death is unknown. Miquel was inclined to place it around $381 \mathrm{H} / 991 \mathrm{CE}$ (at alMuqaddasī, Aḥsan at-taqāsīm [1963], XVI).

87 As in al-Balkhī (d. 322 H/934 CE), iqlīm does not correspond to the Ptolemaic geographical term klima, but rather is a geographical entity, a "country".

88 This word, "highlands", indicates the region including Azerbaijan, Arran and Armenia.

89 Al-Muqaddasī, Ahssan at-taqāsīm (1963), 28. 
side of the river Oxus (Khorasan and Hayțal, i.e. Transoxiana), pointing out a parallel with North Africa and al-Andalus, the two jānibs of al-Maghrib. ${ }^{90}$

Thus, in al-Muqaddasī's usage, Mashriq and Maghrib are not names that indicate the East and the West of the Islamic Empire as a whole, but have a more precise meaning, designating respectively the name of its easternmost region and its westernmost one, from Barqa to al-Andalus. The point is that al-Muqaddasī, in his classification of the regions of mamlakat al-isläm, continues to use the "classical” dichotomy 'arab/'ajam (Arabs/Eastern non-Arabs, that is, Persians), completely overlooking the "newer" Arab/Berber dichotomy. Moreover, in spite of the ' $a \mathrm{rab} /$ 'ajam distinction between the regions, the Islamic oecumene is tacitly divided into three parts: the centre, i.e. Arabia and Iraq; the East, comprising all the Iranian regions, Sind and Transoxiana; and the West, made up of not just North Africa, al-Andalus and Sicily, but also Egypt and Syria.

As with Ibn Hawqal, in al-Muqaddasì's text the description of the countries also begins with jazirat al- 'arab. Here, however, we encounter a further set of justifications for this decision: "because the Ka'ba (bayt Allāh al-harām) and the city of the Prophet are found there, because Islam started spreading from there, and because the caliphs rāshidūn, as well as anșār and muhājirūn resided there", ${ }^{11}$ all reasons which are more religious than geographical.

As for iqlim al-maghrib, "it extends from the borders of Egypt (min tukhūm Mișr) to the Ocean (al-bahr al-muhiț), and it looks like a ribbon (sharița), enclosed between the Mediterranean to the north and the land of the blacks (biläd alsūdān) to the south". ${ }^{92}$ Moreover, as already mentioned, al-Muqaddasi includes it among aqālìm al-'arab. Berbers are neither given any particular weight in his description - in any case far less that in Ibn Hawqal's work - nor are they the object of his appreciation. For example, when informing us that in the province of Setif (Algeria) the countryside is mainly inhabited by Berbers, who are most numerous in Sūs (Morocco), he remarks that they are "a population like those from Khwārizm: their language is unintelligible, their character unpleasant, because they are mean and hard" (ma'a khissa wa-shidda). ${ }^{93}$ Interestingly the same term, shidda, is used by both al-Muqaddasī and Ibn Hawqal, but with a quite different

90 Al-Muqaddasī, Ahsan al-taqāsìm (1906), 216: "wa-qad ja'alnā al-maghrib ma'a al-andalus kahayțal wa-khurāsān".

91 Al-Muqaddasī, Ahsan al-taqāsīm (1906), 67. As for the reasons mentioned by Ibn Ḥawqal, see above, section 5.1 .

92 Al-Muqaddasī, Ahssan al-taqāsīm (1906), 62.

93 Al-Muqaddasī, Aḥsan al-taqāsīm (1906), 243. 
meaning. What in Ibn Hawqal's praise was "force, energy" 94 is in al-Muqaddasī's view "hardness".

Two contemporary and yet different views of the Maghrib emerge: Ibn Hawqal, who declares his own interest in the differences within the Islamic world, highlights the positive aspects of the Berber tribes constituting the bulk of the region's population, emphasising the hegemony of this ethnic group; alMuqaddasī, instead, includes the Maghrib and its inhabitants in the "Arab" regions, focusing perhaps on political hegemony, which in the 4th/10th-century Maghrib was still in Arab hands (the Fātimids), and whose centre would shift to Egypt, in fact part of the same set of aqālim al-'arab. However, this iqlìm al-Maghrib, despite being a vast, thriving province, with a large number of cities and villages, abundant resources, gardens and numerous fortifications, is, in his eyes, "a remote region, with many deserts, difficult and dangerous roads (illā annahu ba'īd al-ațrāf kathīr al-mafāwiz șa'b al-masālik kathīr al-mahālik), placed in a corner of the Islamic world (fi zāwiyat al-islām mawḍu') [...]. There is nobody who wishes to go there, who is curious about it, or who praises its merits ( $f a$-la fỉhi rāghib wa-lā lahu dhāhib wa-lā 'anhu sā'il wa-lā yufaḍ̣iluhu qā'il)". ${ }^{95}$ In the rhymed prose of al-Muqaddasī, al-Maghrib is indeed the far-off and unappealing periphery of mamlakat al-islām.

As far as the eastern boundary of the Maghrib is concerned, for most medieval Muslim geographers it was located in the region of Barqa (modern-day alMarj), ${ }^{96}$ the ancient Cyrenaica, inhabited by the Luwāta Berbers, in far eastern Libya, itself an extremely vague place name as used in medieval Arabic sources. The name, normally rendered as Lübiya, was passed on from the Greeks to the Arabs, who employed it with a wide range of meanings, from place name to province. In some sources Libya is a town in Egypt; in al-Ya 'qūbī it is a district ( $k \bar{r} r a)$ under the authority of Alexandria; and in Yāqūt it is a place located between Alexandria and Barqa. ${ }^{97}$ Libya is, then, a geographical nebula lacking an identity of its own, whose only salient feature is its proximity to and dependence on Egypt, and with it the eastern border of the Maghrib is equally nebulous.

As for the Islamic East, even though Eastern geographers do not appear to conceive of it as a geographical entity in itself in need of a name and fixed boundaries, there are two terms, al-sharq and al-mashriq, which do show up in Muslim

94 See above, section 5.1.

95 Al-Muqaddasī, Ahsan al-taqāsīm (1906), 216.

96 See Despois, “Barḳa”, $E I^{2}$, 1: 1080-1081. See also Goodchild 1976, 255-267.

97 See Goodchild 1976. Mamlūk authors such as al-Maqrīzī, Ibn Duqmāq and al-Qalqashandī, would see Libya as administratively part of Egypt. ("Lỉbiyā. 1" [Ed.], $E I^{2}, 5: 754$ ). 
geographical and historical texts. Al-sharq, the East in general, as Elton Daniel observes, "should probably be understood, at least in the conceptual framework of most medieval Muslim geographers, as referring to everything east of Egypt. Al-mashriq, the eastern lands, refers to a smaller and more distinct component of this territory; as a term, it was certainly in usage by 203/818f., as it appears on a coin of that date". ${ }^{98}$ Indeed, in al-Muqaddasî's work we find this terminological clarification: "Every time we mention Mashriq, we mean with this word the Sāmānid territory", ${ }^{99}$ roughly corresponding, as André Miquel observes, to the following regions: Khorasan, Transoxiana, Sijistan, Jurjan, the region of Rayy and Tabaristan. ${ }^{100}$ Moreover, al-Muqaddasī states, "When we use the word Sharq, we add to these territories (i.e. al-Mashriq) the regions of Fars, Kerman and Sind". ${ }^{101}$ The geographer also establishes a parallelism between the two pairs Mashriq/Sharq and Maghrib/Gharb: "the term Maghrib indicates the region with this name (al-maghrib fa-huwa al-iqlim); Gharb adds to it Egypt and Syria (Shām)". ${ }^{102}$ From this definition of Maghrib - which refers to his own description of its territory as stretching "from the borders of Egypt to the Ocean" - it can be inferred that in any case the region's identity was well known. It is also interesting to note that al-Muqaddasī's definition of Gharb is fundamentally very close (excepting the obvious absence of Anatolia, which was at that time still under Byzantine rule) to that of "the Western Islamic World" as defined by the New Cambridge History of Islam, which served as the point of departure for this chapter. On the other hand, regions such as Arabia and Iraq fall outside his conception of the Sharq. In fact, these regions represent "the centre", the former being the religious hub, and the latter - at least ideally in al-Muqaddasī's time - the political hub of mamlakat al-isläm, as 4th/10th-century geographers called the territories roughly corresponding to the realm which Sunnī jurists, a century and a half before, chose to name dār al-islām. ${ }^{103}$ In spite of the great changes of the 4th/10th century, which witnessed both the demise of 'Abbāsid political authority, and the

98 Daniel 2010, 448. See also Miquel, "Mashrik", $E I^{2}, 6: 709$.

99 Al-Muqaddasī, Aḥsan al-taqāsìm (1906), 7: "wa-kullamā qulnā al-mashriq fa-hiya dawlat āl sāmān".

100 Al-Muqaddasī, Aḥsan at-taqāsīm (1963), 24.

101 Al-Muqaddasī, Ahssan al-taqāsīm (1906), 7.

102 Al-Muqaddasī, Aḥsan at-taqāsīm (1963), 24; al-Muqaddasī, Aḥsan al-taqāsīm (1906), 7.

103 In fact, while the geographers' definition is territorial, the meaning of the term dār in legal texts is much more complex. For examples and a discussion on this subject, see Calasso 2010, 281-286, 289-290. 
rise of the Fāțimid and Umayyad Caliphates in North Africa and al-Andalus, Eastern Muslim geographers of the time indeed persisted in representing the whole of the Islamic territories as a unitary reality, mamlakat al-islām.

Al-Muqaddasì's is therefore a tripartite representation, in which the central and eastern portions, despite the distinction between ' $a r a b$ and ' $a$ jam, seem to form a block (evidence of the fact that three centuries after the conquest, the Arab/Persian dichotomy is not seen as such anymore), at the western border of which lies al-Maghrib. There is still a margin of uncertainty about where Egypt should be placed in this framework. When the geographer specifies what he means by the terms Sharq and Gharb, he includes Egypt in the Gharb, along with Syria and the Maghrib, the westernmost region of the West. However, at the beginning of the section entitled "iqlìm Mișr" al-Muqaddasī states, "Its righteousness spreads to the East and to the West (wa-birruhu ya'ummu al-sharq wa-lgharb), as God situated it between the two seas and raised its reputation in both East and West". ${ }^{104}$ Moreover, from a topographical point of view, as we have seen, Fustat is defined as the faṣl bayna al-Maghrib wa-diyār al-'arab. Although included among the Gharb regions, Egypt seems to resist this inclusion, instead acting as a bridge between East and West.

In summary, in the presentation of the regions, pride of place is always accorded to Arabia, diyār al- 'arab, a feature common to the works of al-Ișțakhrī, Ibn Hawqal and al-Muqaddasī. Arabia, of course, is not "the centre of the empire", as Iraq was for al-Ya'qūbì, but it deserves the first place as the cradle of Islam and as the Arabs' homeland.

The systematic description of the Islamic regions from west to east can be found in both al-Ișțakhrī and Ibn Hawqal. More complex is the order in which alMuqaddasī lists the 'arab and 'ajam provinces, in both cases proceeding from east to west to finally return to the east, tracing two circular itineraries. ${ }^{105}$ Each author emphasizes what he considers the best region: Iran (and Fārs in particular) for al-Ișțakhrī, Iraq for Ibn Ḥawqal and al-Muqaddasī. Still, above and beyond their explicit declarations, Ibn Hawqal focuses the bulk of his description not on Iraq but on Iran, and al-Muqaddasī, who cannot hide his admiration for his native Palestine, describes al-Shām (Syria) extensively, neglects Iraq and dedicates almost half of his work to the 'ajam regions. However, although the weight of these accounts is located decidedly in the East, the Maghrib is by no means left out. With the boundary between East and West consistently running through Egypt,

104 Antrim 2012, 128 (al-Muqaddasī, Ahsan al-taqāsīm [1906], 193).

105 Martinez-Gros 1998, 321. 
the West is indisputably a significant part of the depiction these geographer-travellers make of the mamlaka.

\section{Mashriq and Maghrib as seen by Western geographers, 5 th-6th/11th-12th centuries}

Until the 4th/10th century the approaches we have just seen constituted the dominant, Eastern view of the Islamic West. However, the 5th/11th and 6th/12th centuries saw the emergence of two great Western geographers, the Andalusi alBakrī and the Moroccan al-Idrīsī, whose work would not only greatly enrich the available information about the western lands of Islam, but would also draw attention to a broader horizon, in which the frontier between Mashriq and Maghrib would become a secondary concern.

Al-Bakrī's Kitāb al-Masālik wa-l-mamālik, written ca. 461 H/1068 CE, presents the perspective of a geographer from al-Andalus - "with al-Shariff al-Idrīsī, the greatest geographer of the Muslim West and one of the most characteristic representatives of Arab Andalusian erudition in the 5th/11th century". ${ }^{106}$ He witnessed the Almoravids' arrival in the Iberian peninsula and died an old man in Córdoba in $487 \mathrm{H} / 1094 \mathrm{CE}$.

The work opens with a long introduction on the history of the world, from Creation to Muhammad - just like al-Ṭabarī in his Ta'rīkh - followed by a description of the Arabian peninsula (which is complemented by a section dedicated to religion in pre-Islamic Arabia), before moving on to a general discussion of the seven "climates" (sg. iqlìm, pl. aqālimm). The strictly geographical part of the work begins in the east. However, unlike Eastern geographers who proceed from west to east within the mamlakat al-islām, al-Bakrī begins from the lands outside of it, firstly India (mamlakat al-Hind), ${ }^{107}$ followed by China and Central Asia, thus aiming for a kind of "universal” geography.

The times had changed, and the perspective of the 4th/10th-century Eastern geographers, who had intentionally circumscribed their descriptions to mamlakat al-islām - nonetheless identifying a boundary between its eastern and western portions - was abandoned in favour of a wider perspective. Thus, the book addresses, in often-untidy sequences, non-Islamic countries in the east, in the north (various regions of Europe), and in the south ("the country of the blacks",

106 Lévi-Provençal, “Abū 'Ubayd al-Bakrī”, $E I^{2}, 1: 159$.

107 Al-Bakrī, al-Masālik (1992), 1: 241. 
bilād al-sūdān). One of the most original features which has been recognised in his work is actually the number of pages that al-Bakrī dedicates not only to the Islamic West, but also - although overshadowed by al-Idrīsī's famous account to Christian Europe. Over roughly one hundred pages he describes the peoples that inhabit it: in order of appearance we can find Slavs, Franks, Galicians, Bulgarians, Hungarians, Rūm of Byzantium and of Rome (including a long description of the city); and, as well as the inhabitants of the most important islands of the Mediterranean, he also describes regions such as Macedonia, Thrace, and Thessalia. On the eve of the Reconquista, al-Bakrī acknowledges the newly acquired weight of the Christian West. Its awakening is full of threats for Islam, shifting the Andalusi geographer's gaze both to the north (Europe) as well as to the Maghrib. ${ }^{108}$

The second original element of the work, as observed by various authors, the approximately 190 pages of the Arabic text of his Kitāb al-Masālik wa-l-mamālik dedicated to North Africa, thus making it our most important source on the medieval Maghrib after Ibn Hawqal's geography. Unlike the Eastern Muslim geographers of the 4th/10th century, al-Bakrī was not himself a traveller, and yet the information he gathered on the Maghrib far exceeds that of his wayfaring predecessors.

Contrary to what one might expect, although the author was born in and in all likelihood never left al-Andalus, in his Kitāb al-Masālik wa-l-mamālik he dedicates very little space to the Iberian peninsula. As observed by Emanuelle Tixier, the book's structure indicates a change in the balance of power between al-Andalus and North Africa. The Maghrib is no longer the contested territory of the Umayyads of al-Andalus and the Fātimids, but a breeding ground for new military forces. It is a space in which Islam is clearly dominant and of which al-Andalus, by then no more than a frontier march of mamlakat al-islām, is but an extension. ${ }^{109}$

Breaking with the Andalusi geographers who came before him, such as Aḥmad al-Rāzī (d. ca. 344 H/955 CE), al-Warrāq (d. 363 H/973-4 CE) and al- 'Udhrī (d. $478 \mathrm{H} / 1085 \mathrm{CE}$ ), who focused on the Iberian peninsula - and whose works have come down to us only in a handful of fragments - al-Bakrī chooses to focus on the entire geographic unit stretching from Egypt to the Atlantic. He is intent on making an inventory of this space, rendering visible its internal differences based on political divisions and on the various forms of belonging to Islam. This register of groups and divisions encompasses Kairouan, the centre of Mālikī

108 Tixier 2011, 372.

109 Tixier 2011, 373. 
Sunnism; Tahert, the capital of a Khārijī principality for over a century; Fez, founded by the 'Alid branch of the Idrīsids, who ruled al-Maghrib al-aqșa ("the far West”, i.e. present-day Morocco) until the end of the 4th/10th century; and the Fāțimids, Ismā 'ìlī Shī 'ìs, who after taking power in Ifrīqiya went on to conquer Egypt and founded Cairo, where they continued to rule in al-Bakrī's time. The once unprecedented space that Ibn Hawqal dedicated to North Africa a century earlier has shrunk by comparison and, what is more, the Maghrib itself is now divided into a western, central and eastern region of its own.

Besides the Maghrib, al-Bakrī also dedicates a considerable section to Egypt, from the pre-Islamic period to his own time. But taken as a whole, in this broad picture the division between Maghrib and Mashriq, the Islamic West and East, seems to fade into the background. North of the Mediterranean and south of the Sahara, other regions, other populations now deserve attention, although it would be in al-Idrīsī's Kitāb Rujār (1154) that Europe would cease to play the supporting actor in the geopolitical framework of the Mediterranean and take on the lead role.

Al-Idrīsī, who like al-Bakrī was not a geographer-traveller, wrote his work as a commission for the Norman king Roger II of Sicily in the mid-6th/12th century. To quote Gabriel Martinez-Gros, with his geography "Idrisi franchit les frontières d'un monde musulman qu'il avait lui même quitté pour le service des princes normands de Sicile". ${ }^{110}$ The subject of his geographic work is the known world, reaching as far as China to the east; and, above all, Europe is given an unprecedented amount of space (mainly in the 5th, 6th and 7th climates). ${ }^{111}$ On the contrary, in the overall organisation of the work, Arabia is no longer given a central position, as was the case in the works of al-Ișțakhrī, Ibn Hawqal and al-Muqaddasī. This is one of the effects of the way in which al-Idrīsī structured his work, going back to the division of the earth into seven horizontal climate zones (iqlim, aqālìm), but separating them from west to east with ten meridian lines, thus obtaining a seventy-box grid. The world itself is thus divided into two halves, east and west, separated by the vertical line that divides the fifth and the sixth section.

The idea of an internal division of the Islamic world between Maghrib and Mashriq is no longer significant, while a western and a central Maghrib are explicitly mentioned for instance in the first section of the first climate: "Bijāya is part of the central Maghrib. The merchants of this city have business dealings with those of the far Maghrib, as well as with those of the Sahara and the East";

110 Martinez-Gros 1998, 329: "Idrisi crosses the frontiers of the Muslim world, which he had already left to serve the Norman kings of Sicily".

111 Al-Idrīsī, La première géographie de l’Occident (1999), 255-464. 
"Fez is the axis and the central point of western Maghreb". ${ }^{112}$ Arabia itself, bilād $a l$ - $a r a b$ or jazirat al-'arab, which 4th/10th-century Eastern geographers had made the starting point of their descriptions of mamlakat al-islām, is now divided from south to north into climate zones, thereby losing visibility. In short, alIdrīsī's monumental work seems to reflect, in the words of Henri Bresc and Annliese Nef, "un effort immense de construction d'un nouvel objet scientifique, le monde saisi dans son ensemble, sans exclusive". ${ }^{113}$

\section{Western travellers and geographers from the late 6 th/12th century through the 7 th/13th century}

That the issue of boundaries and hierarchy between the East and the West of the Islamic world remained nevertheless significant, was revealed, from the late 6th/12th century through the 7th/13th century, by a number of travellers and geographers from the Maghrib. This fact is most clear in the works of three authors: the famous Andalusi traveller-pilgrim Ibn Jubayr (d. 614 H/1217 CE), the less famous Moroccan traveller al-'Abdarī, who wrote his Rihla maghribiyya in 686 H/ $1288 \mathrm{CE}$, and his contemporary, Andalusi geographer Ibn Sa`̄id (d. 685 H/ 1286 CE). In his Rihla (578-581 H/1183-1185 CE), Ibn Jubayr, who set out from Granada in the time of the Almohads, constantly compares the Maghrib and the Mashriq. Egypt, where he is made to feel like a foreigner, appears as the gateway to an East at once admirable and reprehensible, commended for its science and scorned for its lack of religious unity, which conversely he asserts to be a strong point of the Maghrib. One hundred years after his time, the Moroccan al-'Abdarì's criticism of Egypt in his Rihla is so vitriolic that the pages depicting the despicable customs of the inhabitants of Cairo almost seem to be a literary exercise in invective. Moreover, he openly identifies the Fātimids, its founders, as the source of all the city's evils. ${ }^{114}$

Particularly intriguing is the figure of the Andalusi geographer Ibn Sa'īd alMaghribī, a contemporary of the Moroccan traveller al-'Abdarī. As pointed out by Víctor de Castro in his contribution to this volume, of the fifteen chapters in Ibn

112 Al-Idrīsī, La première géographie de l'Occident (1999), 77, 130, 153, 165.

113 Bresc/Nef 1999, 52: "an immense effort to construct a new scientific subject, the world taken in its entirety, without privileging one area over another”.

114 Calasso 2014, in particular 202-204. 
Sa '̄id's Kitāb al-Mughrib fì hulā al-Maghrib, six are dedicated to Egypt, three to Ifrīqiya and the Maghrib, and six to al-Andalus, the Christian kingdoms, and northern Europe: a rather surprising geography, with Egypt included within the Islamic West. In his other works, however, Egypt appears variously as part of the West, part of the East, or, as in al-Ghușūn al-yāni 'a, a central region between East and West receiving its own section. ${ }^{115}$ To complicate matters even more, in other writings Ibn Sa'ìd's harsh criticism of the city of Cairo, where he lived for many years, is reminiscent of al-'Abdarì's, although less venomous. ${ }^{116}$

Ibn Sa'îd's inclusion of Egypt in the Maghrib would not go unnoticed. A century later, Ibn Faḍl Allāh al-'Umarī (d. 749 H/1349 CE), the well-known polymath and high-ranking administrator of the Mamlūk sultanate, would firmly oppose Ibn Sa'īd's inclusion of Egypt in the Maghrib, ascribing it to his partiality toward his own land (ta'așșub li-bilädihi), ${ }^{117}$ and employing an entire section of his encyclopaedic work Masālik al-abșār fi mamālik al-amșār to refute the Andalusi author's claims. ${ }^{118}$ This debate, as well as Ibn Sa'īd's shifting positions, in any case reveals that between the 7 th/13th century and the 8 th/14th century the question of whether Egypt belonged to the Maghrib or the Mashriq had become a controversial one. Clearly there was more at stake than just geography; the debate touched on the balance of power both within North Africa, and between the eastern and western Mediterranean. Is it possible to read in Ibn Sa'īd's inclusion of Egypt in the Maghrib a desire to level the playing field between the two halves of the Islamic world? ${ }^{119}$ Or, put in slightly different terms, is it to be viewed as an attempt to strengthen the image of the western part of the Islamic world by annexing, so to say, Egypt?

This period saw the political equilibrium of the Mediterranean shift drastically in favour of Europe, and, in the Islamic West, witnessed the collapse of the Almohad Empire. In light of such phenomena, perhaps it is not by chance that the architectural marvels of Ancient Egypt, a testament to the country's great

115 In the eighth chapter of this work, Ibn Sa'id collects the biographies of 7th/13th-century authors and categorizes them as Eastern and Western. See Castro's article in this volume.

116 See Marín 2005, 220 ff. Ibn Sa īd's passages on Cairo have been translated and annotated by Blachère 1969, 18-26.

117 Ibn Faḍl Allāh al- 'Umarī, Masālik al-abṣār (2010), juz’ 5, faṣl 1, 14; see also faṣl 2, 33.

118 On the debate generated by Ibn Sa'īd's "maghribization” of Egypt, especially among authors of the Mamlūk period, and in particular Abū al-Fidā' (672-732 H/1273-1331 CE), Ibn Faḍl Allāh al- 'Umarī (700-749 H/1301-1349 CE), and al-Maqrīzī (d. 845 H/1442 CE), see Víctor de Castro's article in this volume. I am grateful to the author for having allowed me to read a draft of his paper prior to publication.

119 This hypothesis is entertained by Víctor de Castro. 
past, became an object of particular interest among Muslim authors. At the end of the 6th/12th century Ibn Jubayr seems to anticipate this trend, expressing all his admiration for the ancient Egyptian temple of Akhmim, and painstakingly describing it. ${ }^{120}$ Since, at the same time, the comparison between Maghrib and Mashriq is a kind of leitmotiv of his travelogue, before concluding, it is worth taking a closer look at his Rihla.

\section{Mashriq and Maghrib, Maghāriba and Mashāriqa, in Ibn Jubayr's travelogue}

Ibn Jubayr's account of his pilgrimage to Mecca and journey back to al-Andalus (578-581 H/1183-1185 CE) treats the division between Mashriq and Maghrib as a matter of fact. Like the main representatives of 4th/10th-century Arabic geography, he emphasizes the differences between the Maghrib - where he feels he belongs - and the unfamiliar Mashriq, lending them even greater prominence on the basis of his personal experience as a pilgrim. His entire travelogue is full of comparative observations about the Maghrib and the Mashriq, Easterners and Westerners. The eye of the traveller picks up on differences, establishes hierarchies, and perceives oppositions, clearly suggesting that it is not just a matter of geographical belonging, but of two separate cultural domains within Islam. The "strange" behaviour of the Eastern people is described in detail, be it their funeral customs, their peculiar way of greeting and addressing each other, or their habit of walking with their hands behind their backs. The devotion they show towards pilgrims returning from Mecca - in Damascus as well as in Baghdad - appears as "the opposite of what we were used to in the Maghrib" (didd mā i'tadna fi al-maghrib). The teaching methods, too, are different "in these Eastern lands" (bihādhihi al-bilād al-mashriqiyya), the Qur'ān is only learnt by heart, while poetry is used to learn how to write. There are also a few notes on certain linguistic differences, such as the case of Islamic monasteries (al-ribātāt), which "they call khawāniq". ${ }^{121}$

The great changes taking place since the late 5th/11th century in the Mediterranean and within the Muslim world itself are reflected in the very structure of Ibn Jubayr's travelogue. The traveller's emphasis on the division of the Islamic

120 On this subject, see Calasso 2019.

121 See Ibn Jubayr, Travels (1952), 310, Rihla (1907), 294-296; Travels (1952), 300, Riḥla (1907), 286; Travels (1952), 283, Rihla (1907), 272; Travels (1952), 297, Rị̣la (1907), 284. 
world into Mashriq and Maghrib coexists with his stress on Islam's unifying imprint on the urban landscape, as seen in the systematic way in which he counts, describes, and even measures, the buildings representing what we might call "institutional" Islam. ${ }^{122}$ It is as if the shifting balance of power in the Mediterranean in favour of Latin Christians - in parallel, within Islam, to the political upheaval connected to the decline of the supremacy of the East and the rise of new powers in the West, from the Fātimids to the Almohads ${ }^{123}$ - also aroused in him a strong need to affirm his belonging to a world which is recognisable in the whole of its territories by certain common features, thus a unitary world, and to enhance its image by appropriating its most visible and prestigious past.

After setting out from Granada, Ibn Jubayr headed to Ceuta, where he boarded a Genoese ship. After a long sea voyage, in Egypt he finally encountered "the East", or, more precisely, a reality other than the Maghrib, in turn becoming a foreigner himself, a gharīb. From this point on we find in his travelogue that everything concerning the Maghribis constantly attracts his attention. Every mention of them is accompanied by something positive: e.g. "to Mecca God brought from the Maghrib men skilled in tillage and husbandry who created in it gardens and sown lands", ${ }^{124}$ while in Damascus "they trust only strangers from the Maghrib" 125 to watch over a garden, or supervise a hammām and keep the bathers' clothes as well as to manage a mill or take children to school. ${ }^{126}$ Yet the Maghribis, including Ibn Jubayr, are perceived and see themselves as "foreigners" in these Eastern countries - Egypt, Hejaz, Iraq and Syria.

While Ibn Jubayr establishes a sort of hierarchy between East and West, which appears to favour the former, ${ }^{127}$ at the same time he feels the need to create a balance, extolling the merits of the Maghrib as well. It is true that the East is at the top of the "knowledge" ladder: the young people of "our Maghrib" ( $m a$ -

122 See Calasso 1999.

123 See Jansen/Nef/Picard 2000, 16-25.

124 Ibn Jubayr, Travels (1952), 119; Rihla (1907), 122.

125 On the possible origins of Syria's Maghribis, about which Ibn Jubayr himself provides a wealth of information, see Cahen 1973, 207-209, while on the Maghribi colony in the next century, see Pouzet 1975.

126 Ibn Jubayr, Travels (1952), 289; Riḥla (1907), 278.

127 Some of Ibn Jubayr's verses, quoted in Ibn al-Khațîb’s Ihātạa, show an unconditional admiration for the East: "There is no comparison between East and West: the East possesses all the merits indeed" (la-yastawī sharq al-balad wa-gharbuhā / al-sharq ḥāza al-faḍl bi-stihqāq). Ibn alKhațīb's biographical entry on Ibn Jubayr is reported in the introduction to Wright's edition of Ibn Jubayr's Rihla (1907), 2-10. 
ghribunā) are warmly encouraged to travel to the East - particularly to Damascus - for their studies, ${ }^{128}$ and Eastern preachers are said to have no peers in the Maghrib. ${ }^{129}$ Yet the East is also a place of religious divisions: "in the Eastern countries" you find nothing but "sects and heretical groups and schisms", while "there is no Islam save in the Maghrib lands". This statement is followed by an explicit homage to the Almohads: "there is no justice nor truth except among the Almohads and they are the last legitimate imams of this time". ${ }^{130}$ In other passages of the Rihla, Ibn Jubayr even hints that many Egyptians believe in signs announcing a coming Almohad conquest of Egypt and other Eastern countries. ${ }^{131}$

There is, however, one exception: Șalāh al-Dīn, the just sultan, for whom Ibn Jubayr expresses unreserved admiration for having abolished all the iniquitous taxes imposed by the Fātimids, and for his heroic, ceaseless jihād against the Franks. It is in this contradictory celebration of both the Almohads and Șalāh alDīn that we can perceive the tension between the "local" sense of belonging of Ibn Jubayr as a Muslim from al-Andalus, a Maghribi, and his sense of belonging to the greater dār al-islām, whose internal divisions he cannot help noting during the course of his journey, but which he tries to depict as a unitary reality, mainly by the constant attention he reserves for the buildings - Friday mosques, $m a$ drasas, hospitals, hammāms - representing Islam throughout its lands.

As for the East, the Mashriq, it is not so easy to identify what exactly it corresponds to in Ibn Jubayr's mind. While for him even Egypt - where as soon as he lands he feels like a foreigner - is clearly no longer the Maghrib, Syria is more decidedly "Eastern", ${ }^{132}$ as its inhabitants sometimes do "the opposite of what we were accustomed to in the Maghrib". ${ }^{133}$ This is the Arab East. However, starting with his stay in Mecca, Ibn Jubayr becomes increasingly aware of the existence of an even "more eastern East": the non-Arab East as seen through Maghribi eyes. First there are the 'ajam, the Persians, with a religious sentiment so intense that it sometimes upsets him (as in the case of one 'ajami pilgrim who becomes so

128 Ibn Jubayr, Travels (1952), 298; Riḥla (1907), 285.

129 Ibn Jubayr, Travels (1952), 233: "We marvelled at their excellence in comparison with the speakers we knew in the west” (Rihla [1907], 224).

130 Ibn Jubayr, Travels (1952), 73; Rihla (1907), 78. On such pro-Almohad statements by Ibn Jubayr, in the broader framework of the relationships between the Almohads and the Māliki scholars of al-Andalus, see Viguera 2005, $719 \mathrm{ff}$.

131 Ibn Jubayr, Travels (1952), 74; Riḥla (1907), 79.

132 Ibn Jubayr, Travels (1952), 298: "All these eastern cities are of this fashion, but this city (i.e. Damascus) is more populous and wealthy. Whoever of the young men of the Maghrib seeks prosperity, let him move to these lands (...) in the pursuit of knowledge” (Rihla [1907], 285).

133 Ibn Jubayr, Travels (1952), 300; Riḥla, 286. 
overcome with emotion that he faints). ${ }^{134} \mathrm{He}$ is also astounded at their skill with languages, as in the case of a preacher from Khorasan who had perfectly mastered Arabic and Persian, "employing them together with a lawful magic of rhetoric" and who deftly replied to every question ("In this manner the preachers of these eastern lands meet [...] the copious shower of questions that fall upon them"). ${ }^{135}$ However, there are also the Ghuzz, Turks who, arriving at Mecca alongside the Khorasanians on the pilgrimage caravan from Iraq, express their religious emotionality with a violence that Ibn Jubayr clearly disapproves of and distances himself from. ${ }^{136}$ They are al-a'äjim al-aghtām, "the barbarous-tongue foreigners"; the intensifier al-aghtām gives the term 'ajam a pejorative connotation that seems to hint at an otherness which is more than linguistic. In the month of dhū al-hijja, the Ka'ba is opened every day for them: "The throngings of these men, the way in which they hurled themselves upon the noble door, their collisions which each other [...] was something that never more horrible was seen". ${ }^{137}$ Just as al-Bakrī and al-Idrīsī gave the Maghrib an east, a centre and a west, Ibn Jubayr depicts a Mashriq full of distinct shades of meaning.

\section{Historical overview and concluding remarks}

At the end of this itinerary, we can attempt to draw a picture in which the shifting political equilibrium within the Islamic world as well as the Mediterranean as a whole, intertwines with different forms of categorization of the world emerging in multiple textual genres. At the time of the caliph Hārūn al-Rashīd, from the late 2nd/8th century to the early 3rd/9th century, jurists such as Abū Yūsuf and, above all, al-Shaybānī, both disciples of Abū Ḥanīfa, and their younger contemporary al-Shāfi 'i (d. 204 H/820 CE), introduced in their legal treatises two notions destined to enjoy a long future: dār al-islām and dār al-harb. This pair of abstract legal concepts summed up a binary categorisation of the world that was essential in order to deal with norms related to warfare, and, additionally, with any other kind of relationship between the inhabitants of territories under Muslim domination and the "outside" world. No definition is given, but the terms are there, constantly employed in the casuistry being analysed; apparently they do not need an

134 Ibn Jubayr, Travels (1952), 143; Rihla (1907), 142.

135 Ibn Jubayr, Travels (1952), 186-187; Rịla (1907), 181. See also Travels (1952), 233; Riḥla, 224.

136 See Calasso 2008, 256-258.

137 Ibn Jubayr, Travels (1952), 186; Rihla, (1907), 180. 
explanation, although their usage will make it clear that jurists have different positions concerning their definition. Is dār al-islām a territorial-jurisdictional notion, or does it refer instead to the principle of the personality of law? The answer to such questions would condition different ideas about where to place the boundary between these two entities, dār al-islām and dār al-harb. The fact remains that this binary categorization conveys the idea of a world divided into two separate and opposing realms.

This theoretical construction came into being in an imperial context, with Iraq at its centre, and the jurists who coined this binary categorization of the world were members of the entourage of the 'Abbāsid rulers. The political unity of the empire's heartland was still mostly in place, even though al-Andalus had been lost almost half a century earlier to the Umayyad family, who laid the foundations of their return to power in this faraway western province. Likewise, part of present-day Morocco was by then in the hands of the 'Alid branch of the Idrīsids. Yet Egypt would remain under direct rule of the 'Abbāsids until Ibn Tulūn (approximately mid-3rd/9th century), and even when in the year $184 \mathrm{H} /$ $800 \mathrm{CE}$ the government of Ifrīqiya was officially entrusted to Ibrāhīm Ibn alAghlab, this was by decision of the 'Abbāsid Caliph Hārūn al-Rashīd, in whose name the region was to be ruled.

It would be almost a century before geographers such as Ibn Khurradādhbih and Ibn Wāḍị al-Ya'qūbì would undertake the description of the countries (buldān) that constituted the territories of the caliphate. Besides his Kitāb alBuldān, al-Ya 'qūbì would also write one of the first "universal” works of history, his Ta'rīkh (a history from Adam up to the reign of Caliph al-Mu'tamid, who was in power at that time). He would be followed a few decades later by al-Tabarī and his monumental and "universal" History of the Prophets and Kings.

Unlike the jurists to whom we owe the binary dār al-islām and dār al-harb, geographers like al-Ya'qūbì, and after him the three greats of the 4th/10th century, al-Ișțakhrī, Ibn Hawqal, and al-Muqaddasī, were also travellers who wandered through Islamic countries far and wide, including its westernmost regions. Interestingly, while they make constant reference to mamlakat al-islām, "the empire of Islam" - this "greater regional category of Muslim belonging”, ${ }^{138}$ a realm "which loosely conforms to the territorial extent of Muslim suzerainty in the midtenth century" 139 - they themselves identify a division internal to the mamlaka,

138 I am quoting one of its most recent definitions; see Antrim 2012, 100.

139 According to Antrim, "this lack of a clear focal point reflects the reality of multiple political centers in the period" (Antrim 2012, 100); on the contrary, Miquel $(1967,273)$, considered the idea 
that which separates Mashriq and Maghrib, the East and West of the Islamic world.

The 4th/10th century was indeed a turning point. While the political fragmentation of the Islamic Empire reached its peak and rival caliphates proliferated, the two legal categories of dār al-islām and dār al-harb crystallized as terms, ${ }^{140}$ after having been in flux for more than a century. This was also the period in which Eastern geographers attested to the need to recognize and render visible different identities within the Islamic world, identities whose existence was not relevant to the abstract legal notion of dār al-islām. Internal differences were brought to the fore, and made to converge on another binary, Mashriq/Maghrib. This binary, whose literal meaning merely refers to two cardinal points, is linked to the importance acquired, in these geographers' view, by the western region, namely North Africa west of Egypt, a region which, in conjunction with the rise of the Fātimids, was for the first time "recognized".

As for the difference, highlighted by Claude Cahen, between geographers and historians in the Islamic East, it can be seen, more than in their vision itself, mainly in the ways they express a vision they both share of an Islamic world divided into two halves. Whereas the geographer-travellers of the 4th/10th century provide detailed descriptions of the Maghrib, by marking its territorial boundaries as well as the ethnic and cultural features which distinguish it from the rest of the Islamic world starting from Egypt, Eastern historians outline a similar divide with their own silence, by choosing to ignore in their works the events which took place in the regions west of Egypt after the Arab conquest. When they begin to concern themselves extensively with the Maghrib, starting with Ibn al-Athīr (early 7th/13th century) - the first to devote considerable attention and long sections of his work to the history of North Africa and Iberia - this interest coincides chronologically with the rise of the Berber Almohad empire, unifying North Africa from Morocco to Tripolitania, and proves to be highly dependent on the historical sources of al-Andalus, which by then had begun to circulate in the East.

Explicitly perceived through the eyes of 4th/10th-century Eastern geographers in spatial and ethnic terms, implicitly established by the silence of Eastern Muslim historians of the same period, the distinction/opposition Mashriq/Maghrib thus emerged and became consolidated between the rise of the Fātimids and the construction of the Almohad Empire. Indeed, in this period the territorial

of mamlakat al-islām in these works as a fiction at odds with the reality of political decentralization on the ground in the mid-4th/10th century.

140 In fact from the 4th/10th century onwards all literary genres, starting with Tafsïr literature, attest to the circulation of the dār al-islām/dār al-ḥarb binary. See Tottoli 2017, 110. 
frontier separating the Islamic East and West seems to correspond to the boundary between "orthodoxy" - symbolically represented by the 'Abbāsid caliphate, as well as by the political powers which formally acknowledged its authority and the two doctrinally heterodox political powers which established themselves in North Africa between the 4th/10th century and the 6th/12th century.

In this span of time, starting from the moment the Fātimids publicly rose to power in Ifrīqiya, wresting this region away from the theoretical control of Baghdad's caliphs, it is as if there was a sudden reversal in the role and image of the Maghrib. Until the 4th/10th century it was a peripheral region where Easterners of noble descent escaping implacable enemies sought refuge - starting from the Umayyad 'Abd al-Raḥmān al-Dākhil, the future emir of al-Andalus, to the 'Alid Idrīs b. 'Abdallāh, who survived the Fakhkh massacre and founded the Idrīsid dynasty in al-Maghrib al-aqșā-, where rebels were exiled, ${ }^{141}$ or else where groups of "extremist” dissidents like the Khārijites or the Ismā īlīs secretly organized their propaganda. From the 4th/10th century, however, the Maghrib became the breeding ground of heterodox movements looking eastward. But this would just be an interlude. The cultural features bound to characterize Maghribi identity in a lasting way - most importantly the nearly total adhesion of these societies to Maliki "orthodoxy" - would only become firmly established after the fall of the Almohad Empire. Nevertheless, it was during this interlude that the boundary between Mashriq and Maghrib was constructed in medieval Muslim sources.

And yet, an inextricable web of elements makes it difficult to separate East and West into their component parts. The source of the Fātimids' power - its founder and doctrines - was undoubtedly Eastern, although the dynasty received the decisive military support of a Berber people, the Kutāma, thanks to whom the Fātimids were able to take over the regions of Ifrīqiya - along with Sicily, previously conquered by the Aghlabids - and Egypt, with the later addition of part of Syria. By contrast, the Almohads' power, as well as doctrinal reform, was promoted by the Berber leader of the Mașmūda tribe, Ibn Tūmart, although by means of an original reworking of doctrines of undeniable Eastern origin, such as $\mathrm{Mu}$ 'tazilism and Shī'ism. Indeed, as Muhammad Talbi has pointed out, quite frequently in the Muslim West the term mashäriqa, "Easterners", denoted religious belonging more than country of origin: "the Shī'îs are often described in

141 Al-Ya'qūbī, Works, 3: 1272, 1274, 1284. 
Ifrīqiya, after the coming of the Fātimids, as being mashriqīs, even when the persons in question were authentic Maghribis". ${ }^{142}$ In the collection of biographies by al-Qāọī 'Iyāḍ (d. 544 H/1149 CE), several examples can be found of the verbal form tasharraqa, literally "to become orientalised" - with reference to individuals who lived in the Aghlabid period - to indicate that a certain person had converted to Shī'ism. ${ }^{143}$

Conversely, in Ibn Hawqal's description of Egypt, in the version of his work reflecting a significant anti-Fātimid bias - until recently held to correspond to a second stay of the author in the country ${ }^{144}$ - the Ismā îli caliphs are mentioned only as "the Maghribis" and even the foundation of al-Qāhira itself, as well as other architectural structures commissioned by members of the family, remain anonymous, referred to merely as the Maghribis' creations ("The Maghribis founded a city which was named by them al-Qāhira. Its boundaries were traced by Jawhar, the Maghribis' general...”; or, in another passage: “A Maghribi princess had one more Friday-mosque built at al-Qarāfa”). ${ }^{145}$ The negative connotation of the term maghribi $\bar{i}$, as used in this version of the Iraqi geographer Ibn Hawqal's work, perfectly corresponds to that of the derogatory use of the term mashriqi as seen in the above-mentioned biographies by the eminent Ifrīqī Maliki scholar al-Qāḍi 'Iyāḍ. At the end of the 7th/13th century, the Moroccan traveller al-'Abdarī, in his al-Riḥla al-maghribiyya, would only display acrimony and contempt towards Egyptians, particularly the inhabitants of Cairo, exclusively listing their "demerits". ${ }^{146}$ And it is no coincidence that, in the eyes of al-'Abdarī, the main "flaw" of this first "Eastern" capital city is the fact that, ever since its foundation, it had been linked to the Shì'î Ismā'īlī Fātimids.

The fact remains that Egypt, in this intertwining of mutual perceptions, has a unique and shifting role, neither definitely Eastern nor Western, a view that the Maghribi traveller Ibn Baț̣utạ, in the 8th/14th century, would express in describing Alexandria, which, in his words, "thanks to its being set between Maghrib and Mashriq (li-tawașșutihā bayna al-maghrib wa-l-mashriq), combines their various attractions". ${ }^{147}$ In other words, one of the major effects of viewing their own world as divided into two halves, which led Eastern Muslim geographers of the

142 Talbi, "Mashāriḳa", $E I^{2}, 6: 712$. The transliteration has been changed to adapt it to that used in this article.

143 Talbi 1968, 284, 369, 383, 394; and al-Mālikī, Riyāẹ al-nufūs (1994), 2, 502, 338.

144 See Blachère 1969, 3, and Benchekrun's critical remarks (Benchekrun 2016, 194).

145 Blachère $1969,3$.

146 See Calasso 2014.

147 Ibn Bațtūṭa, Voyages (1853), 27. 
4th/10th century to identify a boundary between Maghrib and Mashriq, was to consolidate the image of Egypt's centrality among all the regions of Islam. ${ }^{148}$

\section{Bibliography}

\section{Primary sources}

Al-Bakrī (1992), Kitāb al-Masālik wa-l-mamālik, ed. by A. P. van Leeuwen and André Ferré, Carthage: al-Dār al-'Arabiyya li-l-Kitāb.

Ibn 'Abd al-Ḥakam (1922), Futūḥ Miṣr wa-akhbāruhā, ed. by Charles C. Torrey, New Haven: Yale University Press.

Ibn Bațțūta (1853), Voyages d'Ibn Batoutah. Tome premier, ed. and trans. by C. Defrémery and B. R. Sanguinetti, Paris: Imprimerie impériale.

Ibn Faḍl Allāh al-'Umarī (2010), Masālik al-abṣār fí mamālik al-amșār, ed. n.n., Beirut: Dār alKutub al-'Ilmiyya.

Ibn Ḥawqal, Abū al-Qāsim Muḥammad al-Nașībī (1938-1939), Kitāb Ṣūrat al-arḍ, ed. by J. H. Kramers, Leiden: Brill.

Ibn Ḥawqal (1964), Kitāb Șūrat al-arḍ, trans. by J. H. Kramers and G. Wiet, Configuration de la terre (Kitab surat al-ard), Paris: Maisonneuve et Larose.

Ibn Jubayr (1907), Riḥla, ed. by William Wright and M. J. de Goeje, Leiden - London: E.J. Brill Luzac \& Co.

Ibn Jubayr (1952), The Travels of Ibn Jubayr, trans. by Roland J. C. Broadhurst, London: Cape (repr. Goodword Books, 2016).

Al-Idrīsī, Abū 'Abd Allāh Muḥammad b. Muḥammad b. Idrīs (1970), Kitāb Nuzhat al-mushtāa fĩ ikhtirāa al-āfāq, ed. by A. Bombaci, U. Rizzitano, R. Rubinacci, and L. Veccia Vaglieri, Opus geographicum sive "Liber ad eorum delectationem qui terras peragrare studeant", Naples - Rome.

Al-Idrīsī (1999), La première géographie de l'Occident, trans. by Chevalier Jaubert, revised by A. Nef, Paris: Flammarion.

Al-Ișțakhrī, Abū Isḥāq Ibrāhīm (1927), Kitāb al-Masālik wa-l-mamālik, ed. by M. J. de Goeje, Leiden: Brill.

Al-Mālikī, Abū Bakr 'Abd Allāh b. Muḥammad al-Mālikī (1994), Kitāb Riyāọ al-nufūs, ed. by B. al-Bakkūsh, revised by M. al-'Arūsī al-Mațwī, Beirut: Dār al-Gharb al-Islāmī.

Al-Mas' 'ūdī (1873), Les prairies d'or. Tome septième, ed. and trans. by C. Barbier de Meynard, Paris: Imprimerie Nationale.

148 On the issue of Egypt's uniqueness, see Decobert 1991. As for its centrality, Sam Gellens had pointed out that the biographies of medieval Egyptian 'ulam $\vec{a}$ ' rarely include the term rihla, referring to travel for study - "a normative feature of medieval Muslim education" -, almost as if Egyptians felt that they were self-sufficient with regard to learning, and the ancient vision of Egypt as the centre of the universe had become part of the cultural patrimony of Egyptian Islam (Gellens 1990, 57-58). 
Al-Muqaddasī, Abū 'Abd Allāh Muḥammad b. Aḥmad (1906), Aḥsan al-taqāsīm fì márifat alaqālīm, ed. by M. J. De Goeje, Descriptio imperii Moslemici, Leiden: Brill.

Al-Muqaddasī (1963), Aḥsan at-taqāsīm fĩ márifat al-aqālìm (La meilleure répartition pour la connaissance des provinces), trans. by André Miquel, Damascus: Institut Français de Damas.

Al-Ṭabarī (1991), The History of al-Ṭabarī. An Annotated Translation. Volume XXXIII: Storm and Stress along the Northern Frontiers of the 'Abbāsid Caliphate, trans. by C. E. Bosworth, Albany: State University of New York Press.

Al-Ya'qūbī, Ibn Wāḍị̣ (1892), Kitāb al-Buldān, ed. by M. J. De Goeje, Leiden: Brill.

Al-Ya'qūbī, Ibn Wāọị̣ (1381/1962), Description du Maghreb en 276/889. Extrait du « Kitâb alBuldan », ed. by Henri Pérès, trans. by Gaston Wiet, Algiers: Institut d’Etudes Orientales.

Al-Ya'qūbī, Ibn Wāḍị (2018), The Works of Ibn Wāḍị al-Ya'qūbī. An English Translation, ed. by Matthew S. Gordon, Chase F. Robinson, Everett K. Rowson, and Michael Fishbein, 3 vols., Leiden - Boston: Brill.

\section{Secondary sources}

Abou El Fadl, Khaled (1994), "Islamic Law and Muslim Minorities: the Juristic Discourse on Muslim Minorities from the Second/Eight to the Eleventh/Seventeenth Centuries”, Islamic Law and Society 1/2, 141-187.

Anthony, Sean / Gordon, Matthew S. (2018), “Ibn Wāc̣ih al-Ya'qūbī: A Biographical Sketch”, in: Matthew S. Gordon, Chase F. Robinson, Everett K. Rowson, and Michael Fishbein, eds., The Works of Ibn Wādih al-Ya'qūbĩ. An English Translation, 3 vols., Leiden - Boston: Brill, 1: 9-22.

Antrim, Zayde (2012), Routes and Realms. The Power of Place in the Early Islamic World, Oxford: Oxford University Press.

Bahri, Fathi (2000), “Les 'Adjam al-balad: une minorité sociale d'origine autochtone en Ifrîqiyya aghlabide (III'-IXe siècles)”, in: Henri Bresc and Christiane Veauvy, eds., Mutations d'identité en Méditerranée. Moyen Âge et époque contemporaine, Paris: Bouchène, 67-84.

Benchekrun, Chafik T. (2016), “Requiem pour Ibn Ḥawqal. Sur l'hypothèse de l'espion fatimide", Journal Asiatique 304/2, 193-211.

Blachère, Régis (1969), "L’agglomération du Caire vue par quatre voyageurs arabes du Moyen Âge”, Annales Islamologiques 8, 1-26.

Bonner, Michael (1994), "The naming of the frontier: 'awāṣim, thughūr, and the Arab geographers", Bulletin of the School of Oriental and African Studies 57, 17-24.

Bosworth, C. E. (1985), “'Ajam”, Encyclopædia Iranica, 1/7: 700-701.

Brauer, Ralph W. (1995), Boundaries and Frontiers in Medieval Muslim Geography, Philadelphia: The American Philosophical Society.

Bresc, Henri / Nef, Annliese (1999), “Presentation”, in: al-Idrīsī, La première géographie de l'Occident, trans. by Chevalier Jaubert, Paris: Flammarion.

Brett, Michael (2001), The Rise of the Fatimids: The World of the Mediterranean and the Middle East in the Tenth Century CE, Leiden: Brill.

Cahen, Claude (1970), "Réflexions sur la connaissance du monde musulman par les historiens", Folia Orientalia 12, 41-49. 
Cahen, Claude (1973), “Ibn Jubayr et les Maghrébins de Syrie”, Revue de l'Occident Musulman et de la Méditerranée (Mélanges Le Tourneau) 13-14, 207-209.

Calasso, Giovanna (1999), "Les tâches du voyageur : décrire, mesurer, compter chez lbn Jubayr, Nāṣer-e Khosrow et Ibn Bațțūța”, Rivista degli Studi Orientali 73, 69-104.

Calasso, Giovanna (2008), “Le donne e la Ka'ba: genere e riti del hajj”, in: Daniela Bredi, Leonardo Capezzone, Wasim Dahmash, Lucia Rostagno, eds., Scritti in onore di Biancamaria Scarcia Amoretti, Rome: Edizioni Q, 1: 243-258.

Calasso, Giovanna (2010), "Alla ricerca di dār al-islām. Una ricognizione nei testi di giuristi e tradizionisti, lessicografi, geografi e viaggiatori”, Rivista degli Studi Orientali, Nuova Serie 83, 271-296.

Calasso, Giovanna (2014), “Egypt through Maghrebi eyes. Al-'Abdarī's Rị̣la between Ibn Jubayr and Ibn Khaldūn”, Rivista degli Studi Orientali, Nuova Serie 87, 201-209.

Calasso, Giovanna (2017), “Constructing and Deconstructing the dār al-islām/dār al-ḥarb Opposition: Between Sources and Studies”, in: Giovanna Calasso and Giuliano Lancioni, eds., Dār al-islām/dār al-ḥarb: Territories, People, Identities, Leiden: Brill, 21-47.

Calasso, Giovanna (2019), “A Wondrous Past, a Dangerous Present: The Egyptian Temple of Akhmīm and the Martorana Church in Palermo, as Seen through Ibn Jubayr's Travelogue”, The Medieval Globe 5/2,127-148.

Calasso, Giovanna / Lancioni, Giuliano, eds. (2017), Dār al-islām/dār al-ḥarb: Territories, People, Identities, Leiden: Brill.

Cilardo, Agostino (2008), "Zufar, the Disciple of Abū Ḥanīfa”, in: Daniela Bredi, Leonardo Capezzone, Wasim Dahmash, Lucia Rostagno, eds., Scritti in onore di Biancamaria Scarcia Amoretti, Rome: Edizioni Q, 2: 391-408.

Daniel, Elton L. (2010), “The Islamic East”, in: Chase F. Robinson, ed., The New Cambridge History of Islam. Volume 1: The Formation of the Islamic World Sixth to Eleventh Centuries, Cambridge: Cambridge University Press, 448-507.

Decobert, Christian (1991), “Entre Moïse et Pharaon. L'Egypte après la conquête arabe”, Egypte/Monde arabe 7, 27-54.

Despois, J., "Barka”, The Encyclopaedia of Islam, 2nd ed., 1: 1080-1081.

Ducène, Jean-Charles (2017), “Ibn Ḥawqal”, Encyclopaedia of Islam, THREE, Brill Online.

Fierro, Maribel (2010), “Introduction”, in: M. Fierro, ed., The New Cambridge History of Islam. Volume 2: The Western Islamic World Eleventh to Eighteenth Century, Cambridge: Cambridge University Press, 1-18.

Garcin, Jean-Claude (1983), “Ibn Hawqal, l'Orient et le Maghreb”, Revue de l'Occident Musulman et de la Méditerranée 35/1, 77-91.

Gellens, Sam (1990), “The search for knowledge in medieval Muslim societies: a comparative approach", in: Dale Eickelman and James Piscatori, eds., Muslim Travellers: Pilgrimage, Migration, and the Religious Imagination, London: Routledge, 50-65.

Goitein, Shelomo Dov (1967), A Mediterranean Society, 1. Economic Foundations, Berkeley Los Angeles: University of California Press.

Goldberg, Jessica L. (2012), Trade and Institutions in the Medieval Mediterranean: The Geniza Merchants and Their Business World, Cambridge: Cambridge University Press.

Goodchild, Richard G. (1976), "Byzantines, Berbers and Arabs in seventh-century Libya”, in: J. Reynolds, ed., Libyan Studies. Select Papers of the late R.G. Goodchild, London: Paul Elek, 255-267.

Gordon, Matthew S. (2001), The Breaking of a Thousand Swords. A History of the Turkish Military of Samarra (A.H.200-275/815-889 C.E.), New York: State University of N.Y. Press. 
Gordon, Matthew S. (2018), “Introduction: The Ya'qūbī Translation Project”, in: Matthew S. Gordon, Chase F. Robinson, Everett K. Rowson, and Michael Fishbein, eds., The Works of Ibn Wādiḥ al-Ya'qūbī. An English Translation, 3 vols., Leiden - Boston: Brill, 1: 1-8.

Heffening, W. / [Schacht, J.], “Ḥanafiyya”, The Encyclopaedia of Islam, 2nd ed., 3: 162-164. Jansen, Ph. / Nef, A. / Picard, C. (2000), La Méditerranée entre pays de l'islam et monde latin (milieu Xe-milieu XIIle siècle), Paris: Sedes.

Kennedy, H. (2001), The Armies of the Caliphs: Military and Society in the early Islamic State, London - New York: Routledge.

Kramers, J. H. (1995), “al-Nïl”, The Encyclopaedia of Islam, 2nd ed., 8: 37-43.

Lancioni, Giuliano (2017), “Concluding Remarks. The terminological array”, in: Giovanna Calasso and Giuliano Lancioni, eds., Dār al-islām/dār al-ḥarb: Territories, People, Identities, Leiden: Brill, 415-425.

Lecomte, Gérard (1957), "L'Ifrîqiya et l'Occident dans le Kitâb al-Ma'ârif d'Ibn Qutayba”, Cahiers de Tunisie 5/19-20, 253-255.

Lev, Yaacov (2017), “The Perception of the Others. Rum and Franks (Tenth-Twelfth Centuries)”, in: Giovanna Calasso and Giuliano Lancioni, eds., Dār al-islām/dār al-ḥarb: Territories, People, Identities, Leiden: Brill, 63-73.

Lévi-Provençal, E., “Abū 'Ubayd al-Bakrī”, The Encyclopaedia of Islam, 2nd ed., 1: 155-157.

Manzano Rodriguez, Miguel Ángel (2017), “El Maghreb desde Oriente: un acercamiento al Libro de los países de Aḥmad al-Ya'qūbī”, in: Fátima Roldan and Alejandra Contreras, eds., Paisajes, espacios y objetos de devoción en el Islam, Sevilla: Editorial Universidad de Sevilla (EUS), 143-160.

Marçais, Georges (1957), “La Berbérie au IXe siècle d'après El-Ya'qoubî”, in: Mélanges d'histoire et d'archéologie de l'Occident musulman. Tome I. Articles et conférences de G. Marçais, Alger: Imprimerie Officielle, 37-49.

Marín, Manuela (2005), “Viajeros magrebíes en Egipto: una mirada conflictiva”, in: Juan Pedro Monferrer Sala and M. D. Rodríguez Gómez, eds., Entre Oriente y Occidente. Ciudades y viajeros en la Edad Media, Granada: EUG, 215-229.

Martinez-Gros, Gabriel (1998), “La division du monde selon Idrîsî”, in: Michel Balard and Alain Ducellier, eds., Le partage du monde, Paris: Publications de la Sorbonne, 315-334.

Miquel, André (1967), La géographie humaine du monde musulman jusqu'au milieu du $11^{e}$ siècle. 1: Géographie et géographie humaine dans la littérature arabe des origines à 1050, Paris: Mouton \& Editions de l'Ecole des Hautes Etudes en Sciences sociales.

Miquel, André (1972), “L’Egypte vue par un géographe arabe du IVe/Xe siècle”, Annales Islamologiques 11 (Volume dédié à la mémoire de G. Wiet), 109-139.

Miquel, André (1973), “La description du Maghreb dans la géographie d'al-lçt'akhri”, Revue de l'Occident musulman et de la Méditerranée 15-16, 231-239.

Miquel, André (1983), “La géographie arabe après l'an mil”, in: Popoli e paesi nella cultura altomedievale, Spoleto: Centro Italiano di Studi sull'Alto Medioevo, 1: 153-174.

Miquel, André, “Ibn Ḥawḳal”, The Enclyclopaedia of Islam, 2nd ed., 3: 786-788.

Miquel, André, “Mashrik", The Enclyclopaedia of Islam, 2nd ed., 6: 720.

Molina, Luis (2020), "The Integration of al-Andalus in Islamic Historiography: The View from the Maghrib and the Mashriq", in: M. Fierro, ed., Routledge Handbook of Muslim Iberia, Abingdon, Oxon - New York: Routledge, 572-585.

Morgan, David O. / Reid, Anthony (2010), “Introduction: Islam in a plural Asia”, in: D. O. Morgan and A. Reid, eds., The New Cambridge History of Islam. Volume 3: The Eastern Islamic World Eleventh to Eighteenth Centuries, Cambridge: Cambridge University Press. 
Pouzet, Louis (1975), “Maghrébins à Damas au VII/XIIle siècle”, Bulletin d'Etudes Orientales 28, 167-199.

Rowson, Everett K. (2018), “Manuscripts, Printed Editions, and Translations of al-Ya'qūbī’s Works”, in: Matthew S. Gordon, Chase F. Robinson, Everett K. Rowson, and Michael Fishbein, eds., The Works of Ibn Wādih al-Ya'qūbī. An English Translation, 3 vols., Leiden - Boston: Brill, 1: 23-28.

Talbi, Muhammad (1966), L'émirat aghlabide, Paris: Adrien-Maisonneuve.

Talbi, Muhammad (1968), Biographies aghlabides extraites des Madārik du Cadi 'lyāọ (1083 1149), Tunis: Imprimerie Officielle.

Talbi, Muhammad, “Maghāriba”, The Encyclopaedia of Islam, 2nd ed., 5: 1159-1161.

Talbi, Muhammad, "Mashāriḳa”, The Encyclopaedia of Islam, 2nd ed., 6: 712-713.

Tixier, Emmanuelle (2011), “Bakrī et le Maghreb”, in: Dominique Valérian, ed., Islamisation et arabisation de l'Occident musulman médiéval (VIIe-XIle siècle), Paris: Publications de la Sorbonne, 369-384.

Tottoli, Roberto (2017), "Dār al-islām/dār al-ḥarb in the Tafsīr by lbn Jarīr al-Tabarī and in Early Tradition”, in: Giovanna Calasso and Giuliano Lancioni, eds., Dār al-islām/dār al-harb: Territories, People, Identities, Leiden: Brill, 108-124.

Viguera, M. J. (2005), “Las reacciones de los Andalusíes ante los Almohades”, in: P. Cressier, M. Fierro and L. Molina, eds., Los Almohades: problemas y perspectivas, Madrid: CSIC, 2: 705-735.

Walker, Paul E. (2008), "Kutāma, Kalbids and Other Westerners: the Maghāriba in Cairo", in: Atti del Convegno "I Fatimidi e il Mediterraneo" (Palermo 3-6 dicembre 2008), Alifbâ 22, 45-57.

Yver, Georges, “al-Maghrib”, The Encyclopaedia of Islam, 2nd ed., 5: 1183-1184. 